\title{
Ulusal ve küresel makroekonomik faktörlerin gelişen borsalar üzerindeki etkileri: Türkiye ve BRICS ülkeleri üzerine ampirik bir araştırma ${ }^{1}$
}

\section{The effects of national and global macroeconomic factors on emerging stock markets: An empirical research on Turkey and BRICS countries}

\author{
İsmail Karataş2 \\ Mehmet İslamoğlu ${ }^{3}$
}

\begin{abstract}
${ }^{1} \mathrm{Bu}$ araştırma, Doç. Dr. Mehmet İslamoğlu' nun danışmanlığında tamamlanan, İsmail Karataş'a ait “Ulusal ve Küresel Makroekonomik Faktörlerin Gelişen Borsalar Üzerindeki Etkileri: Türkiye ve BRICS Ülkeleri Üzerine Ampirik Bir Araştırma" isimli doktora tezinden üretilmiştir.
\end{abstract}

2 Dr. Öğr. Üyesi, Bayburt Üniversitesi, Bayburt, Türkiye, ismailkrts34@gmail.com

ORCID: 0000-0002-1237-4670

${ }^{3}$ Doç. Dr., Karabük Üniversitesi, Karabük, Türkiye,

$\underline{\text { mehmetislamoglu@karabuk.edu.tr }}$

ORCID: 0000-0002-4416-0888

\section{Sorumlu Yazar/Corresponding Author:}

İsmail Karataş,

Bayburt Üniversitesi, Bayburt, Türkiye, ismailkrts34@gmail.com

Başvuru/Submitted: 23/10/2021

Revizyon/Revised: 30/11/2021

Kabul/Accepted: 19/12/2021

Yayın/Online Published: 25/12/2021

Atıf/Citation: Karataş, İ., \& İslamoğlu, M., Ulusal ve küresel makroekonomik faktörlerin gelişen borsalar üzerindeki etkileri: Türkiye ve BRICS ülkeleri üzerine ampirik bir araştırma, bmij (2021) 9 (4): 1611-1639, doi:

https://doi.org/10.15295/bmij.v9i4.1959
Öz

Bu çalışma, ulusal ve küresel makroekonomik faktörlerin Türkiye ve BRICS (Brezilya, Rusya, Hindistan, Çin ve Güney Afrika) ülkelerine ait hisse senedi endeksleri üzerindeki etkilerinin belirlenmesi amacıyla ele alınmış ve hazırlanmıştır. Bu amaç doğrultusunda çalışmanın analizlerinde Ocak 2003 - Aralık 2016 dönemine ait aylık veriler kullanılmıştır. Federal fon oranları, küresel emtia fiyat endeksi, MSCI gelişmiş ülkeler için sermaye piyasası endeksi, tüketici fiyat endeksi, sanayi üretim endeksi, dar tanımlı para arzı ve ABD Doları bazlı reel döviz kuru çalışmanın açıklayıcı değişkenleridir. Araştırmanın açılanan değişkenleri ise bu ülkelerin borsa endeksi kapanış fiyatlarıdır. Bu bağlamda her ülkeye ilişkin bir model oluşturulmuş olup ilgili sonuçlara ulaşılması amacıyla Doğrusal Otoregresif Dağıtılmış Gecikme (ARDL) yaklaşımı uygulanmıştır. Ayrıca çalışmada Doğrusal Olmayan Otoregresif Dağıtılmış Gecikme (NARDL) yaklaşımı da kullanılmıştır. Bu kapsamda küresel emtia fiyat endeksi, dar tanımlı para arzı ve ABD Doları bazlı reel döviz kuru açılayıcı değişkenler; bu ülkelerin borsa kapanış fiyatları ise açıklanan değişkenler olarak modellere dahil edilmiştir. ARDL yaklaşımı analizi sonuçlarına göre değişkenler bağlamında istatistiksel olarak anlamlı etkilerin olduğu görülmüştür. NARDL yaklaşımı analiz sonuçlarına göre değişkenler bağlamında kısa dönem ve uzun dönem asimetrik etkilerin olduğu tespit edilmiştir.

Anahtar Kelimeler: Ulusal Makroekonomik Faktör, Küresel Makroekonomik Faktör, Borsa, BRICS, ARDL, NARDL

Jel Kodları: B22, G10, G15

\begin{abstract}
This study was handled and prepared to determine the impact of national and global macroeconomic factors on the stock exchanges of Turkey and the BRICS (Brazil, Russia, India, China and South Africa) countries. For this purpose, monthly data from January 2003 - December 2016 were used to analyse the study. Federal funds rate, global commodity price index, MSCI World Index, consumer price index, industrial production index, narrow-defined money supply and U.S. Dollar-based real exchange rate are the explanatory variables of the study. The explained variables of the research are the closing prices of the stock market index of these countries. In this context, each country set a model, and the Linear Autoregressive Distributed Lag (ARDL) approach was applied to reach the related results. In addition, Nonlinear Autoregressive Distributed Lag (NARDL) approach was used in the study. In this context, the global commodity price index, narrow-defined money supply, and U.S. Dollar-based real exchange rate were the explanatory variables; the closing prices of the stock market of these countries as dependent variables were included in the models. According to the ARDL approach analysis results, it was observed that there were statistically significant effects in the context of the variables. Furthermore, according to the results of the NARDL approach analysis, it was determined that there were short-term and long-term asymmetric effects in the context of the variables.
\end{abstract}

Keywords: National Macroeconomic Factor, Global Macroeconomic Factor, Stock Market, BRICS, ARDL, NARDL

Jel Codes: B22, G10, G15 


\section{Extended Abstract}

\section{The effects of national and global macroeconomic factors on emerging stock markets: An empirical research on Turkey and BRICS countries}

\section{Literature}

It is known that all stock exchanges worldwide have started to develop since the 1950s. The globalization of markets, the increase in communication opportunities, the advancement in computer technologies, the facilitation of financial institutions' entry into the market in many countries and the increase in direct financing opportunities are considered as the reason for the development of stock exchanges. The people's savings are transferred to companies as capital through stock markets. Instead of high-risk and short-term loans borrowed by companies from banks, stock markets offer companies lower risk and long-term funds. Thus, the transformation of funds into investments contributes to the progress of the national economy. In addition, if we consider this situation in terms of companies listed in the stock market, the market capitalization of these companies increase gradually, and their equity becomes solid. In this context, the substantial benefits of stock exchanges can be listed as providing liquidity, quotation, being an economic indicator, public involvement to capital markets and creating funds (Karan, 2011, p. 35-36). Stock markets also play an essential role in economic development, as they increase efficiency in the formation and allocation of capital (Tadesse, 2004). In this context, Levine (1991) and Levine and Zervos (1998) are among the first to propose endogenous growth models that explain the relationship between financial development and long-term economic growth. Likewise, Levine and Zervos (1998) document that well-functioning stock markets encourage economic growth, capital accumulation and productivity increases.

\section{Research subject}

The research aims to investigate the effects of national and global macroeconomic factors on the leading stock indices of developing countries. In this context, Turkey and BRICS countries (Brazil, Russia, India, China and South Africa) are selected as developing countries. In addition, global macroeconomic factors, federal funds rate, global commodity price index and MSCI capital market index of developed countries are adopted. Furthermore, consumer price index, industrial production index, narrow measure of the money supply (M1) and US Dollar-based actual exchange rate variables are determined as national macroeconomic factors.

\section{Research purpose and importance}

This study, which was carried out considering the importance of stock markets within the scope of stock exchanges and the place of the BRICS community in the world economy, was handled and prepared to determine the effects of national and global macroeconomic factors on the stock indices of Turkey and BRICS countries. In this context, it is accepted that the changes in macroeconomic factors are transmitted to the stock exchanges of the nations. Thus this may be a channel that affects the economic growth of these countries. On the other hand, BRICS countries are the primary buyers of global investment flows and the immediate global consumers of commercial goods. In addition, BRICS stock markets offer opportunities for investment, speculation and risk diversification. Therefore, it is thought that international investors are interested in whether these stock markets and macroeconomic factors correlate. In line with these explanations, besides Turkey, BRICS countries are involved in the research study to determine the effects of macroeconomic factors on stock indices. Accordingly, the results of the research study are considered to be necessary.

\section{Contribution of the article to the literature}

When the related literature concerning the research study is examined, it is observed that there are many academic papers on both global and national factors influencing the national stock markets. In this context, some of the national factors affecting the stock markets are fiscal policy, monetary policy and other financial needs. On the other hand, it is seen that some of the global factors are the monetary policy of the leading economies, fiscal policies and financial markets (Ansari \& Sensarma, 2019, p. 130). However, when some other studies by researchers are evaluated within the scope of examining the effects of macroeconomic factors on developing countries' stock market indices, there are a limited number of studies on global macroeconomic factors. In addition, since this limited number of studies were applied to only some of the developing countries, it is thought that the current research results are more comprehensive and will contribute to filling an important gap in the relevant literature.

\section{Design and method}

\section{Research type}

This article, based on a quantitative approach, is a research article.

\section{Research problems}

Research problems to be answered in the context of the primary purpose of the research:

1- Do the macroeconomic factors selected within the scope of the research have linear effects on the stock indices of Turkey and BRICS countries?

2- Do the macroeconomic factors selected within the scope of the research have non-linear effects on the stock indices of Turkey and BRICS countries?

\section{Data collection method}

In order to be used in the analysis of the study, the stock indices data of Turkey and BRICS countries were extracted comparatively from the official websites of Yahoo Finance and Investing within the framework of the monthly data for January 2003-December 2016. FFR (Effective Federal Funds Ratio), M1 (Narrow Measure of Money Supply) and CPI (Global Commodity Price Index) data were obtained from the Federal Reserve Bank of St. Louis (FRED). In contrast, RER (Real Exchange Rate) and INF (Inflation (Consumer Price Index)) data were extracted from the Website of the International Monetary Fund (IMF). MSCI World Index (MSCI Capital Markets Index for Developed Countries) data was removed from the official website of Morgan Stanley Capital 
International. IP (Industrial Production Index) data of Turkey, Brazil, Russia and India were obtained from the International Monetary Fund (IMF). In contrast, IP data for China and South Africa were taken from the World Bank (WB).

\section{Quantitative analysis}

Considering the primary purpose of the research, in analyzing the data with appropriate methods, unit root tests, ARDL approach, NARDL approach and diagnostic tests were performed. In this context, various statistical techniques such as cointegration and autoregressive procedures were used to determine the short and long term effects of the macroeconomic factors selected within the scope of the research on the stock indices of Turkey and BRICS countries.

\section{Research model}

By examining the relevant literature, the macroeconomic factors that impact the stock exchanges were determined, and a research model was formed using these factors. In this context, the general functional representation of the research model, which is the focus of the study, is expressed as:

$$
S M P_{t}=f\left(F F R_{t}, M S C I_{t}, C P I_{t}, M 1_{t}, R E R_{t}, I N F_{t}, I P_{t}\right)
$$

The SMP in this functional notation represents the closing price of the stock index on the stock market. In addition, when the research model is represented by the Ordinary Least Squares method:

$$
L S M P_{t}=\beta_{0}+\beta_{1} F F R_{t}+\beta_{2} L M S C I_{t}+\beta_{3} L C P I_{t}+\beta_{4} L M 1_{t}+\beta_{5} L R E R_{t}+\beta_{6} L_{I N F_{t}}+\beta_{7} L I P_{t}+u_{t}
$$

\section{Findings and discussion}

According to the results of ARDL approach analysis: the federal funds rate on Brazil, Russia, India and China; the global commodity price index on Turkey, Brazil, Russia, China and South Africa; the consumer price index on China; the money supply on Turkey, Brazil and India; the real exchange rate on Turkey, Brazil and Russia were found to have statistically significant effects. According to the results of the NARDL approach analysis: the global commodity price index in the context of Turkey, Brazil, Russia, India and China; the money supply in the context of Russia and China; the exchange rate in the context of Turkey and Brazil were found to have long-term asymmetric effects. In addition, the global commodity price index in the context of Turkey, Brazil, Russia, China and South Africa; the money supply in the context of Turkey, Brazil, China and South Africa and the exchange rate in the context of Turkey, Brazil, Russia, India and South Africa were found to have short-term asymmetric effects. In line with the purpose of the study, coefficient estimates of the models were obtained, and comments and comparisons were made regarding these findings within the framework of Turkey and BRICS countries.

\section{Conclusion, recommendation and limitations}

As a result of the research, recent information contributing to the literature has been reviewed. The study results have substantial benefits for policy makers, investors, and researchers. In this context, the results can help policy makers determine their management strategies depending on the factors covered by the research. Furthermore, investors can predict the change in stock index prices based on the conditions of these macroeconomic factors. Therefore the research results can help reduce the cost of estimating this change. Accordingly, it is believed that the results provide investors with information about the course of their investment positions in the relevant stock markets in the face of a change in these factors. However, in further studies, the scope of the research can be expanded by including stock markets of other developing countries in the analysis. The research period covers monthly data between January 2003-December 2016 for Turkey and BRICS countries. In further studies, new results that will contribute to the literature can be reached by diversifying the period and frequency. The stock index was adapted as the only indicator for the countries involved in the research. In this context, since some countries (Russia, India, China and South Africa) have more than one indicator index, research results can be diversified by including other stock indices in the analysis within the framework of a single country or the BRICS community. Furthermore, if different countries (developed and developing countries) are selected, and other econometric models are used, it is possible to reach findings different from this research study. 


\section{Giriş}

Dünyadaki tüm menkul kıymet borsalarının, 1950'li yıllardan itibaren gelişmeye başladığı kabul edilmektedir. Dünya pazarlarının küreselleşmesi, iletişim olanaklarının artması, bilgisayar teknolojilerindeki ilerleme, finansal kurumların birçok ülkede piyasaya girmelerinin kolaylaştırılması ve doğrudan finansman imkanlarının artması; menkul kıymet borsalarının gelişmesinin nedeni olarak görülmektedir. Halkın tasarrufları, şirketlere sermaye olarak menkul kıymet borsaları aracılığıyla yönlendirilmektedir. Şirketler tarafından bankalardan alınan yüksek riske ve düşük vadeye sahip krediler yerine bu borsalar şirketlere çok daha düşük riske ve uzun vadeye sahip kaynaklar sunmaktadır. Bu doğrultuda kaynakların yatırıma dönüşmesi, ulusal ekonominin ilerlemesine katkı sağlamaktadır. Ayrıca borsaya kote olan şirketler açısından durum değerlendirildiğinde ise, bu firmaların değerleri artmış ve özkaynakları sağlamlaşmıştır. Bu bağlamda, menkul kıymet borsalarının önemli faydaları; likidite sağlama, fiyat oluşturma, ekonomik gösterge olma, mülkiyeti tabana yayma ve kaynak oluşturma olarak sıralanabilmektedir (Karan, 2011, s. 35-36). Ayrıca sermayenin oluşumunda ve tahsisatında verimliliği arttırdıkları için borsalar ekonomik kalkınmada da önemli bir rol oynamaktadır (Tadesse, 2004). Bu kapsamda Levine (1991) ve Levine ve Zervos (1998), finansal gelişme ile uzun dönemli ekonomik büyüme arasındaki ilişkiyi açıklayan endojen büyüme modellerini önerenlerin ilkleri arasında yer almaktadırlar. Aynı şekilde Levine ve Zervos (1998), iyi işleyen borsaların; büyümeyi, sermaye birikimini ve verimlilik artışlarını desteklediğini belgelemektedir.

Borsaya ilişkin bu açıklamalar gelişen ülkeler bağlamında değerlendirildiğinde özellikle son yüzyılda, bu ülkelerin çoğunluğu hızlı bir ekonomik büyüme yaşamıştır. Gelişen ülkelerin bazılarının, gelecekte gelişmiş ülkeler haline geleceğinden ve uluslararası yatırımcılar için geniş bir çeşitliliğin faydalarının bulunmasından dolayı portföy yöneticilerinin ve yatırımcıların portföylerine, gelişen piyasaları dahil etmeleri gerektiği belirtilmektedir (Barry, Peavy ve Rodriguez, 1998). Bu bağlamda küreselleşme ve finansal serbestleşme, uluslararası yatırımcıların gelişen piyasalara daha güvenli yatırım yapmalarını sağlamaktadır (Jiang, Fu ve Ruan, 2019). Ayrıca bu gelişen ülkelerin, temel sermaye ihtiyaçlarının önemli bir bölümünü hisse senedi portföy yatırımlarından karşıladıkları da ileri sürülmektedir (Karan, 2011, s. 35).

Gelişen ekonomiler arasında yer alan BRICS (Brezilya, Rusya, Hindistan, Çin ve Güney Afrika) ülkeleri ise, ekonomik performansları açısından en ilgi çekici beşli olarak görülmektedir (Jiang vd., 2019). Bu çerçevede, BRICS ülkelerinin küresel ekonomideki önemlerinin hızla artığı görülmektedir. BRICS, dünya nüfusunun yaklaşık \%40'ını oluşturan dünyadaki en büyük ülke gruplarından biri olup bu ülkelerin ekonomik yükselişleri, oldukça etkileyicidir. Örneğin, BRICS ekonomilerinin 1990 yılı dünya GSYİH'nin yaklaşık \%11'lik payından, 2018 yılı dünya GSYİH'nin yaklaşık \%32'lik bir payına yükseldiği görülmektedir. Ayrıca BRICS ülkelerinin, küresel ekonomiyle iyi bir şekilde bütünleştiği ve bu bütünleşmeden yararlandığı kabul edilmektedir. Örneğin, Hindistan ve Çin küresel tedarik zincirleriyle yakından ilişkiliyken Brezilya, Güney Afrika ve Rusya'nın ise doğal kaynaklarını ihraç etmenin kazanımlarından faydalandıkları görülmektedir. Bu kapsamda BRICS ekonomilerinin, son birkaç on yılda uluslararası ticaretin ve emtia tüketiminin önemli tarafları olduğu kabul edilmektedir. $\mathrm{Bu}$ unsurlar, BRICS hisse senedi piyasalarını küresel yatırımlar için uygun bir hedef haline getirmektedir (Ansari ve Sensarma, 2019, s. 131). Ekonomik gelişmenin yanı sıra, BRICS borsaları daha yüksek fakat daha öngörülebilir ortalama getiri üretmekte ve daha etkili uluslararası çeşitlilik sağlayan portföylerin oluşturulmasına imkân tanımaktadır. Elektronik ticaret kullanımı, içeriden öğrenenlerin ticareti yasalarının uygulanması ve iç borsalar arasındaki bağlantı gibi bir finansal reform dalgası da bu ülkelerde gerçekleştirilmiştir (Jiang vd., 2019). Bu nedenlerden dolayı çok sayıda uluslararası yatırımcı, portföy yöneticisi ve politika yapıcı BRICS borsalarıyla özellikle ilgilenmektedir (Chkili, 2016; Raza, Shahzad, Tiwari ve Shahbaz, 2016; Mensi, Hammoudeh, Nguyen ve Kang, 2016). Ek olarak, BRICS'e yönelik artan bu ilginin, Türkiye'nin büyümesiyle aynı yönlü bir seyir izlediği de ileri sürülmektedir (Bacik, 2013, s. 758).

Menkul kıymet borsaları kapsamındaki hisse senedi piyasalarının önemi ve BRICS topluluğunun dünya ekonomisindeki yeri göz önünde bulundurularak gerçekleştirilen bu çalışmanın temel amacı, ulusal ve küresel makroekonomik faktörlerin gelişen piyasalardan Türkiye ve BRICS ülkelerine ait hisse senedi endeksleri üzerindeki etkilerinin incelenmesidir. Bu kapsamda makroekonomik faktörlerdeki değişiklikler, ülkelerin borsalarına iletildiği ve dolayısıyla bu ülkelerin ekonomik büyümelerini etkileyen bir kanal olabileceği kabul edilmektedir. BRICS ülkeleri ise küresel yatırım akımlarının temel alıcıları ve ticari malların temel küresel tüketicileri arasında yer almaktadır. Ayrıca BRICS borsaları; yatırım, spekülasyon ve risk çeşitlendirme fırsatları da sunmaktadır. Dolayısıyla uluslararası yatırımcıların, bu borsalarla makroekonomik faktörlerin ortak bir hareket sergileyip sergilemediklerine özellikle ilgi gösterdikleri düşünülmektedir. Bu açıklamalar doğrultusunda, makroekonomik 
faktörlerin hisse senedi endeksleri üzerindeki etkilerinin belirlenmesi amacıyla Türkiye'nin yanında BRICS ülkeleri seçilmiş ve çalışmaya dahil edilmiştir.

Araştırmaya ilişkin literatür incelendiğinde, ulusal borsaları etkileyen hem küresel hem de ulusal birçok faktör üzerine araştırmaların yapıldığı görülmektedir. Bu kapsamda borsaları etkileyen ulusal faktörlerin bazıları; maliye politikası, para politikası ve diğer finansal piyasalar iken küresel faktörlerin bazıları ise önde gelen ekonomilerin para politikası (ABD Merkez Bankası veya Avrupa Merkez Bankası tarafından belirlenen faiz oranları vb.), maliye politikaları ve finansal piyasaları olduğu görülmektedir (Ansari ve Sensarma, 2019, s. 130). Ancak, araştırmacıların yaptığı diğer çalışmalar, makroekonomik faktörlerin gelişen ülkelerin borsa endeksleri üzerindeki etkilerinin incelenmesi kapsamında değerlendirildiğinde; küresel makroekonomik faktörlerin yer aldığı sınırlı sayıda çalışmanın olduğu görülmektedir. Ayrıca sınırlı sayıda yapılan bu çalışmalar, gelişen ülkelerin yalnızca bazılarına uygulandığı için bu araştırma sonuçlarının daha kapsamlı olduğu ve ilgili literatürdeki önemli bir boşluğun doldurulmasına katkıda bulunacağı düşünülmektedir. Çalışmanın bir diğer üstünlüğü, uygulanan zaman serisi analizi yöntemidir. Bu çerçevede, seçilen bazı makroekonomik faktörlerin Türkiye ve BRICS ülkelerine ait hisse senedi endeksleri üzerindeki etkilerinin belirlenebilmesi amaciyla eşbütünleşme yöntemi, hata düzeltme modeli gibi çeşitli istatistiksel teknikler kullanılmıştır. Bu ifadelerle bağlantılı olarak çalışmada, cevabına ulaşılması istenen aşağıdaki temel sorular ele alınmaktadır:

Araştırma kapsamında seçilen makroekonomik faktörlerin, Türkiye ve BRICS ülkelerine ait hisse senedi endeksleri üzerinde doğrusal etkileri var mıdır?

Araştırma kapsamında seçilen makroekonomik faktörlerin, Türkiye ve BRICS ülkelerine ait hisse senedi endeksleri üzerinde doğrusal olmayan etkileri var mıdır?

Bu sorunun cevabına ulaşılması, Türkiye ve BRICS ülkeleri hisse senedi endekslerinin makroekonomik faktörlere karşı sergiledikleri duyarlılıkların anlaşılması kapsamında oldukça önemlidir. Bu cevabın; politika yapıcılara, yatırımcılara ve araştırmacılara bazı önemli faydaları bulunmaktadır. Bu bağlamda araştırma sonuçları, politika yapıcıların seçilen makroekonomik faktörlere bağlı olarak yönetim stratejilerini belirlemelerine yardımcı olabilmektedir. Yatırımcılar, bu makroekonomik faktörlerin koşullarına dayalı olarak ortaya çıkan borsa endeksi fiyatlarındaki değişimi tahmin edilebilmekte ve dolayısıyla araştırma sonuçları, bu değişimi tahmin etme maliyetinin azalmasına yardımcı olabilmektedir. Buna bağlı olarak sonuçların yatırımcılara, bu faktörlerde meydana gelen bir değişim karşısında ilgili borsalardaki yatırım pozisyonlarının seyrine ilişkin bilgiler sunduğu düşünülmektedir. Ayrıca bu araştırma; sonuç, kapsam ve sınırılıklar çerçevesinde yapılacak çalışmalar için bazı görüşler de sunmaktadır.

\section{Literatür taramas1}

Çalışma ile ilgili literatür incelendiğinde birçok yerli ve yabancı araştırmanın olduğu görülmektedir. Buna bağlı olarak çalışmanın bu bölümünde, makroekonomik faktörlerin hisse senedi piyasaları üzerindeki etkilerinin incelendiği ampirik araştırmalar Tablo 1'de tarihsel sırayla sunulmaktadır. 
Tablo 1: Literatür Taraması

\begin{tabular}{|c|c|c|c|c|}
\hline Yazar(lar) & Yöntem & Dönem & Değişken & Sonuç \\
\hline $\begin{array}{c}\text { Mukherjee } \\
\text { ve Naka } \\
(1995)\end{array}$ & $\begin{array}{l}\text { Eşbütünleşme } \\
\text { Testi ve Vektör } \\
\text { Hata Düzeltme } \\
\text { Modeli }\end{array}$ & $\begin{array}{l}\text { 1971:M01- } \\
\text { 1990:M12 }\end{array}$ & $\begin{array}{l}\text { Döviz kuru, para arzı, } \\
\text { tüketici fiyat endeksi, sanayi } \\
\text { üretimi, uzun vadeli devlet } \\
\text { tahvili faiz oranı ve kredi faiz } \\
\text { oranı - Tokyo Borsası Tüm } \\
\text { Hisse Senedi Endeksi }\end{array}$ & $\begin{array}{l}\text { Borsa endeksi ile döviz kuru, sanayi } \\
\text { üretim endeksi ve para arzı değişkenleri } \\
\text { arasında pozitif; enflasyon değişkeni } \\
\text { arasında ise negatif yönlü ilişkilerin } \\
\text { olduğu bulunmuştur. Bununla birlikte } \\
\text { borsa endeksinin devlet tahvili faiz } \\
\text { oranıyla negatif, kredi faiz oranıla ise } \\
\text { pozitif yönlü ilişkilere sahip olduğu } \\
\text { tespit edilmiştir. }\end{array}$ \\
\hline $\begin{array}{l}\text { Moorkerjee } \\
\text { ve Yu (1997) }\end{array}$ & $\begin{array}{l}\text { Engle ve Granger } \\
\text { Eşbütünleşme, } \\
\text { Granger } \\
\text { Nedensellik ve } \\
\text { Çoklu Regresyon }\end{array}$ & $\begin{array}{l}\text { 1984:M10- } \\
\text { 1993:M04 }\end{array}$ & $\begin{array}{l}\text { Dar tanımlı para arzı (M1), } \\
\text { geniş tanımlı para arzı (M2), } \\
\text { döviz kuru ve döviz rezervi - } \\
\text { Singapur Borsa Endeksi }\end{array}$ & $\begin{array}{l}\text { Hisse senedi fiyatları ile dar ve geniş para } \\
\text { arzı arasında eşbütünleşme; M2, hisse } \\
\text { senedi endeksinin Granger nedeni; M1'in } \\
\text { borsa getirisi üzerinde negatif yönde } \\
\text { anlamlı bir etkisi; nominal kur } \\
\text { değişimlerinin öngörülmeyen cari } \\
\text { bileşeninin, hisse senedi fiyatları } \\
\text { üzerinde pozitif yönde anlamlı bir etkisi } \\
\text { olduğu tespit edilmiştir. }\end{array}$ \\
\hline $\begin{array}{l}\text { Durukan } \\
(1999)\end{array}$ & $\begin{array}{c}\text { En Küçük Kareler } \\
\text { Yöntemi }\end{array}$ & $\begin{array}{l}\text { 1986:M01- } \\
\text { 1998:M12 }\end{array}$ & $\begin{array}{l}\text { Enflasyon, faiz oranı, döviz } \\
\text { kuru, para arzı (M1, M2 ve } \\
\text { M2Y) ve sanayi üretim } \\
\text { endeksi - Türkiye IMKB } \\
\text { Hisse Senetleri Endeksi }\end{array}$ & $\begin{array}{l}\text { Hisse senedi fiyatları üzerinde; faiz oranı } \\
\text { negatif yönde; sanayi üretim endeksi } \\
\text { pozitif yönde anlamlı etkilere sahip } \\
\text { oldukları tespit edilmiştir. }\end{array}$ \\
\hline $\begin{array}{c}\text { Nasseh ve } \\
\text { Strauss } \\
(2000)\end{array}$ & $\begin{array}{c}\text { Eşbütünleşme ve } \\
\text { Hata Düzeltme } \\
\text { Modeli }\end{array}$ & $\begin{array}{l}\text { 1962:Q1- } \\
\text { 1995:Q4 }\end{array}$ & $\begin{array}{l}\text { Sanayi üretim endeksi, uzun } \\
\text { vadeli faiz oranları ve } \\
\text { tüketici fiyat endeksi - } \\
\text { Almanya, Fransa, İtalya, } \\
\text { Hollanda, İsviçre ve İngiltere } \\
\text { hisse senedi piyasaları }\end{array}$ & $\begin{array}{l}\text { Tüm araştırma modellerinde } \\
\text { eşbütünleşmenin olduğu görülmüştür. } \\
\text { Ayrıca sanayi üretim endeksi (tüm } \\
\text { ülkeler için pozitif yönlü), kısa (İsviçre } \\
\text { hariç tüm ülkeler için pozitif yönlü) ve } \\
\text { uzun (İtalya ve İsviçre hariç tüm ülkeler } \\
\text { için negatif yönlü) vadeli faiz oranları ve } \\
\text { tüketici fiyat endeksinin (tüm ülkeler için } \\
\text { pozitif yönlü) hisse senedi fiyatları } \\
\text { üzerinde anlamlı etkilere sahip oldukları } \\
\text { görülmüştür. }\end{array}$ \\
\hline $\begin{array}{l}\text { Maghayereh } \\
\text { (2003) }\end{array}$ & $\begin{array}{l}\text { Eşbütünleşme } \\
\text { Yöntemi ve Hata } \\
\text { Düzeltme Modeli }\end{array}$ & $\begin{array}{l}\text { 1987:M01- } \\
\text { 2000:M12 }\end{array}$ & $\begin{array}{l}\text { İhracat, döviz rezervleri, } \\
\text { sanayi üretimi, faiz oranı, } \\
\text { enflasyon ve para arzı (M1) - } \\
\text { Ürdün hisse senedi fiyatları }\end{array}$ & $\begin{array}{l}\text { Eşbütünleşme ilişkisinin olduğu } \\
\text { görülmüştür. İhracat, döviz rezervleri ve } \\
\text { sanayi üretimi değişkenlerinin hisse } \\
\text { senedi fiyatlarıyla pozitif yönde; faiz } \\
\text { oranı ve enflasyon değişkenlerinin ise } \\
\text { negatif yönde anlamlı ilişkilere sahip } \\
\text { oldukları görülmüştür. Ancak para arz1 } \\
\text { (M1) değişkeni ile hisse senedi endeksi } \\
\text { arasında anlamlı bir ilişki olmadığı tespit } \\
\text { edilmiştir. }\end{array}$ \\
\hline $\begin{array}{l}\text { Dritsaki } \\
(2005)\end{array}$ & $\begin{array}{c}\text { Eşbütünleşme ve } \\
\text { Granger } \\
\text { Nedensellik }\end{array}$ & $\begin{array}{l}\text { 1988:M09- } \\
\text { 2003:M06 }\end{array}$ & $\begin{array}{l}\text { Enflasyon, sanayi üretim } \\
\text { endeksi ve k1sa dönem faiz } \\
\text { oranı - Yunanistan Borsa } \\
\text { Endeksi (ASE General Index) }\end{array}$ & $\begin{array}{l}\text { Eşbütünleşme ilişkisinin olduğu } \\
\text { görülmüştür. Ayrıca borsa endeksi ile } \\
\text { sanayi üretim endeksi arasında iki yönlü, } \\
\text { enflasyon ve faiz oranlarından borsa } \\
\text { endeksine doğru ise tek yönlü bir } \\
\text { nedenselliğin olduğu tespit edilmiştir. }\end{array}$ \\
\hline $\begin{array}{l}\text { Gan, Lee, } \\
\text { Yong ve } \\
\text { Zhang } \\
(2006)\end{array}$ & $\begin{array}{l}\text { Johansen } \\
\text { Maksimum } \\
\text { Olabilirlik ve } \\
\text { Granger } \\
\text { Nedensellik }\end{array}$ & $\begin{array}{l}\text { 1990:M01- } \\
\text { 2003:M01 }\end{array}$ & $\begin{array}{l}\text { Enflasyon, döviz kuru, para } \\
\text { arzı (M1), kısa ve uzun vadeli } \\
\text { faiz oranları, döviz kuru ve } \\
\text { gayri safi yurtiçi hasıla - Yeni } \\
\text { Zelanda hisse senedi endeksi }\end{array}$ & $\begin{array}{l}\text { Johansen testi aracılı̆̆ıyla hisse senedi } \\
\text { endeksi ile makroekonomik göstergeler } \\
\text { arasında bir eşbütünleşmenin olduğu } \\
\text { tespit edilmiştir. Ayrıca Granger } \\
\text { nedensellik testi sonucunda ise Yeni } \\
\text { Zelanda hisse senedi endeksinin } \\
\text { makroekonomik faktörler üzerinde } \\
\text { belirleyici bir etkiye sahip olmadığı } \\
\text { görülmüştür. }\end{array}$ \\
\hline $\begin{array}{l}\text { Wang ve } \\
\text { Iorio (2007) }\end{array}$ & $\begin{array}{c}\text { Finansal Varlık } \\
\text { Fiyatlandırma } \\
\text { Modeli - Doğrusal } \\
\text { Regresyon Analizi }\end{array}$ & $\begin{array}{l}\text { 1995:M01- } \\
\text { 2004:M12 }\end{array}$ & $\begin{array}{l}\text { MSCI World Endeksi ve } \\
\text { Hong Kong Borsası - Çin } \\
\text { hisse senedi piyasaları (A, B } \\
\text { ve H hisse senedi piyasaları) }\end{array}$ & $\begin{array}{l}\text { A hisse senedi piyasasının bölünmüş bir } \\
\text { piyasa olduğu görülmüştür. Diğer } \\
\text { taraftan alt dönem testlerinde, A ile B } \\
\text { hisse senedi piyasaları ve A hisse senedi } \\
\text { piyasası ile Hong Kong Borsası arasında } \\
\text { daha üst düzeyde bir bütünleşmenin } \\
\text { olduğu tespit edilmiştir. Ayrıca B ve H } \\
\text { hisse senedi piyasalarının dünya } \\
\text { borsaları ile giderek daha fazla } \\
\text { bütünleştiği yönündeki hipotezin } \\
\text { desteklenmediği görülmüştür. }\end{array}$ \\
\hline
\end{tabular}




\begin{tabular}{|c|c|c|c|c|}
\hline $\begin{array}{l}\text { Yılmaz, } \\
\text { Güngör ve } \\
\text { Kaya (2008) }\end{array}$ & $\begin{array}{c}\text { En Küçük Kareler, } \\
\text { Eşbütünleşme, } \\
\text { Granger } \\
\text { Nedensellik ve } \\
\text { VECM Temelli } \\
\text { Varyans } \\
\text { Ayrıştırma } \\
\text { Yaklaşımları }\end{array}$ & $\begin{array}{l}\text { 1990:M01- } \\
\text { 2003:M12 }\end{array}$ & $\begin{array}{l}\text { Tüketici fiyat endeksi, para } \\
\text { arzı, faiz oranı, döviz kuru, } \\
\text { dış ticaret dengesi ve sanayi } \\
\text { üretim endeksi - Türkiye } \\
\text { İMKB endeksi }\end{array}$ & $\begin{array}{l}\text { Hisse senedi fiyatları bağlamında; } \\
\text { tüketici fiyat endeksi (pozitif yönlü), } \\
\text { döviz kuru (pozitif yönlü), faiz oran1 } \\
\text { (negatif yönlü), para arzı (M1 - pozitif } \\
\text { yönlü) ve dıs ticaret dengesi (negatif } \\
\text { yönlü) değişkenlerinin istatistiksel olarak } \\
\text { anlaml etkilere sahip oldukları; hisse } \\
\text { senedi fiyatı ile tüketici fiyat endeksi, faiz } \\
\text { oranı ve sanayi üretim endeksi } \\
\text { değişkenleri arasında uzun dönemli bir } \\
\text { iliş̧i bulunmuştur. }\end{array}$ \\
\hline $\begin{array}{l}\text { Kandir } \\
(2008)\end{array}$ & $\begin{array}{c}\text { Çoklu Regresyon } \\
\text { Analizi }\end{array}$ & $\begin{array}{l}\text { 1997:M07- } \\
\text { 2005:M06 }\end{array}$ & $\begin{array}{l}\text { Sanayi üretim endeksi } \\
\text { büyüme oranı, tüketici fiyat } \\
\text { endeksi değişim oranı, dar } \\
\text { tanımlı para arzı (M1) } \\
\text { büyüme oranı, döviz kuru } \\
\text { değişim oranı, faiz oranı, } \\
\text { uluslararası ham petrol fiyatı } \\
\text { büyüme oranı ve MSCI } \\
\text { Dünya Endeksi - IMKB } \\
\text { finansal olmayan şirketlerin } \\
\text { hisse senedi getirileri }\end{array}$ & $\begin{array}{l}\text { Döviz kurunun (pozitif yönde), faiz } \\
\text { oranının (negatif yönde) ve MSCI Dünya } \\
\text { Endeksi'nin (pozitif yönde) tüm portföy } \\
\text { getirilerini etkilediği, enflasyonun } \\
\text { etkisinin (pozitif yönde) ise on iki } \\
\text { portföyden yalnızca üçü için anlaml } \\
\text { olduğu ortaya koyulmuştur. Diğgr } \\
\text { taraftan sanayi üretimi, para arzı ve } \\
\text { petrol fiyatlarının hisse senedi getirileri } \\
\text { üzerindeki etkilerinin istatistiksel olarak } \\
\text { anlamlı olmadığ görülmüştür. }\end{array}$ \\
\hline $\begin{array}{l}\text { Humpe ve } \\
\text { Macmillan } \\
\text { (2009) }\end{array}$ & $\begin{array}{c}\text { Vektör Hata } \\
\text { Düzeltme Modeli }\end{array}$ & $\begin{array}{l}\text { 1965:M01- } \\
\text { 2005:M12 }\end{array}$ & $\begin{array}{l}\text { Sanayi üretimi, tüketici fiyat } \\
\text { endeksi, uzun vadeli faiz } \\
\text { oranı, para arzı (M1) - } \\
\text { Japonya ve ABD hisse } \\
\text { senetleri }\end{array}$ & $\begin{array}{l}\text { ABD bağlamında hisse senedi fiyatları ile } \\
\text { sanayi üretimi arasında pozitif yönlü; } \\
\text { hisse senedi fiyatları ile tüketici fiyat } \\
\text { endeksi ve uzun vadeli faiz oranı } \\
\text { arasında ise negatif yönlü bir ilişki } \\
\text { görülmüştür. Ayrı hisse senedi } \\
\text { fiyatları ile para arzı (M1) arasında } \\
\text { pozitif yönlü ancak istatistiksel olarak } \\
\text { anlamlı olmayan bir ilişki bulunmuştur. } \\
\text { Japonya bağlamında ise borsa endeksi ile } \\
\text { sanayi üretimi arasında pozitif; para arzi } \\
\text { arasında ise negatif yönlü bir ilişki tespit } \\
\text { edilmiştir. }\end{array}$ \\
\hline $\begin{array}{l}\text { Mohammed, } \\
\text { Hussain, } \\
\text { Jalil ve Ali } \\
(2009)\end{array}$ & ARIMA Yöntemi & $\begin{array}{l}\text { 1987:Q1- } \\
\text { 2007:Q4 }\end{array}$ & $\begin{array}{l}\text { Sanayi üretim endeksi, döviz } \\
\text { kuru, döviz rezervi, gayri } \\
\text { safi sabit sermaye oluşumu, } \\
\text { enflasyon, faiz oranı ve para } \\
\text { arzı (M2) - Pakistan Karaçi } \\
\text { Borsası }\end{array}$ & $\begin{array}{l}\text { Döviz rezervi, sanayi üretimi ve } \\
\text { enflasyon değişkenlerinin hisse senedi } \\
\text { fiyatları üzerinde pozitif yönde; döviz } \\
\text { kuru, faiz oranı ve para arzı (M2) } \\
\text { değişkenlerinin ise negatif yönde anlamlı } \\
\text { etkilere sahip oldukları görülmüştür. } \\
\text { Diğer taraftan gayri safi sabit sermaye } \\
\text { oluşumunun ise hisse senedi fiyatları } \\
\text { üzerinde istatistiksel olarak anlamlı bir } \\
\text { etkiye sahip olmadığı bulunmuştur. }\end{array}$ \\
\hline $\begin{array}{l}\text { Sayılgan ve } \\
\text { Süslü (2011) }\end{array}$ & $\begin{array}{c}\text { Dengeli Panel Veri } \\
\text { Analizi }\end{array}$ & $\begin{array}{l}\text { 1999:Q1- } \\
\text { 2006:Q4 }\end{array}$ & $\begin{array}{lr}\text { Para arzındaki (M1) } & \text { yüzde } \\
\text { değişim, faiz } & \text { oranı, } \\
\text { GSYİH'deki yüzde değişimi, } \\
\text { döviz kurundaki } & \text { yüzde } \\
\text { değişimi, } & \text { petrol } \\
\text { fiyatlarındaki r yüzde } \\
\text { değişim, tüketici } r \text { fiyat } \\
\text { endeksindeki (enflasyon) } \\
\text { yüzde değişim ve Standard } \\
\text { and Poors 500 endeksinin } \\
\text { getirisi - Arjantin, Brezilya, } \\
\text { Endonezya, Macaristan, } \\
\text { Malezya, Meksika, Polonya, } \\
\text { Rusya, Şili, Türkiye ve } \\
\text { Ürdün hisse senedi getirileri }\end{array}$ & $\begin{array}{l}\text { Enflasyon oranın ve Standart and Poors } \\
500 \text { endeksinin hisse senedi getirisi } \\
\text { üzerinde pozitif yönde anlamlı etkileri } \\
\text { görülmüş iken döviz kurunun ise negatif } \\
\text { yönde anlamlı bir etkiye sahip olduğu } \\
\text { tespit edilmiştir. Bununla birlikte faiz } \\
\text { oranı, gayri safi yurt içi hasıla, para arzı } \\
\text { ve petrol fiyatları değişkenlerinin ise } \\
\text { hisse senedi getirileri üzerinde } \\
\text { istatistiksel olarak anlamlı bir etkiye } \\
\text { sahip olmadıkları görülmüştür. }\end{array}$ \\
\hline $\begin{array}{l}\text { Hosseini, } \\
\text { Ahmad ve } \\
\text { Lai (2011) }\end{array}$ & $\begin{array}{l}\text { Çok Değişkenli } \\
\text { Eşbütünleşme ve } \\
\text { Vektör Hata } \\
\text { Düzeltme } \\
\text { Yaklaşımları }\end{array}$ & $\begin{array}{l}\text { 1999:M01- } \\
\text { 2009:M01 }\end{array}$ & $\begin{array}{l}\text { Ham petrol fiyat1, para arz1 } \\
\text { (M2), sanayi üretimi ve } \\
\text { enflasyon oranı - Hindistan } \\
\text { Bombay Borsası (BSE) } \\
\text { Endeksi ve Çin Şanghay } \\
\text { Borsası (SSE) Endeksi }\end{array}$ & $\begin{array}{l}\text { Uzun dönemde ham petrol fiyatlarındaki } \\
\text { artışı Çin Borsası üzerindeki etkisi } \\
\text { pozitif fakat Hindistan Borsası́nda ise bu } \\
\text { etkinin negatif olduğu görülmüştür. Para } \\
\text { arzının, Hindistan borsaları üzerindeki } \\
\text { etkisi negatif iken Çin üzerinde ise pozitif } \\
\text { etkiye sahip olduğ tespit edilmiştir. } \\
\text { Sanayi üretiminin Çin üzerindeki } \\
\text { etkisinin negatif olduğu ancak } \\
\text { enflasyonun ise bu borsa endeksleri } \\
\text { üzerindeki etkisinin pozitif olduğu } \\
\text { görülmüştür. }\end{array}$ \\
\hline $\begin{array}{l}\text { Kumar } \\
(2011)\end{array}$ & $\begin{array}{l}\text { Eşbütünleşme ve } \\
\text { Granger }\end{array}$ & $\begin{array}{l}\text { 2006:M04- } \\
\text { 2010:M03 }\end{array}$ & $\begin{array}{l}\text { Sanayi üretim endeksi, } \\
\text { toptan eşya fiyat endeksi, } \\
\text { reel döviz kuru, doğrudan }\end{array}$ & $\begin{array}{l}\text { Eşbütünleşme analizi sonucunda } \\
\text { yalnızca hisse senedi endeksi ile toptan } \\
\text { eşya fiyat endeksi arasında bir }\end{array}$ \\
\hline
\end{tabular}




\begin{tabular}{|c|c|c|c|c|}
\hline & $\begin{array}{l}\text { Nedensellik } \\
\text { Yaklaşımları }\end{array}$ & & $\begin{array}{l}\text { yabanc1 yatırımlar, döviz } \\
\text { rezervleri ve dış ticaret } \\
\text { dengesi - Hindistan NSE } \\
\text { Niffty hisse senedi endeksi }\end{array}$ & $\begin{array}{l}\text { eşbütünleşme olduğu görülmüştür. } \\
\text { Ancak Granger nedensellik testi } \\
\text { sonucunda bu iki değişkenin } \\
\text { birbirlerinin nedeni olmadı̆g ortaya } \\
\text { koyulmuştur. }\end{array}$ \\
\hline Li (2013) & $\begin{array}{c}\text { Doğrusal } \\
\text { Regresyon ve } \\
\text { Markov Rejim } \\
\text { Değişim Tekniği }\end{array}$ & $\begin{array}{l}\text { 2000:M01- } \\
\text { 2010:M12 }\end{array}$ & $\begin{array}{l}\text { MSCI World Endeksi - } \\
\text { Şangay ve Shenzhen } \\
\text { Borsaları'nın A ve B hisse } \\
\text { senedi endeksleri ve portföy } \\
\text { endeksleri }\end{array}$ & $\begin{array}{l}\text { Çoğu durum için kısmi bütünleşmenin } \\
\text { pozitif fiyatlı küresel ve ulusal sistematik } \\
\text { riskleri açısından kanıtlar bulunmuştur. } \\
\text { Bununla birlikte sınırlandırılmamış } \\
\text { Şangay B-hisse piyasasının genel olarak } \\
\text { küresel pazardan ayrıldığı tespit } \\
\text { edilmiştir. Ayrıca yerel sistematik riskin } \\
\text { fiyatlandırıldığ1 göz önüne alındığında, } \\
\text { Çin'in uluslararası portföy çeşitliliği için } \\
\text { bir alana sahip olduğu görülmüştürr. }\end{array}$ \\
\hline $\begin{array}{l}\text { Sevinç } \\
(2014)\end{array}$ & $\begin{array}{c}\text { Doğrusal } \\
\text { Regresyon Analizi }\end{array}$ & $\begin{array}{l}\text { 2003:M01- } \\
\text { 2013:M03 }\end{array}$ & $\begin{array}{l}\text { BIST100 endeksi, para arzı } \\
\text { (M2), cari işlemler dengesi, } \\
\text { döviz kuru sepeti, enflasyon } \\
\text { oranı, mevduat faiz oran, } \\
\text { altın fiyatı, ihracatın ithalat } \\
\text { karşlama oranı, sanayi } \\
\text { üretim endeksi ve kapasite } \\
\text { kullanım oranı - BIST30 } \\
\text { hisse senedi endeksi getirisi }\end{array}$ & $\begin{array}{l}\text { BIST100 Endeksinin, cari işlemler } \\
\text { dengesinin, döviz kurunun, enflasyonun } \\
\text { ve ihracatın ithalatı karşılama oranının } \\
\text { BIST30 üzerinde pozitif; para arzının, } \\
\text { mevduat faiz oranının ve altın } \\
\text { fiyatlarındaki değişimin ise negatif } \\
\text { yönde anlamlı etkilere sahip oldukları } \\
\text { görülmüştür. Ancak sanayi üretim } \\
\text { endeksinin ise BIST30 hisse senedi } \\
\text { endeksi üzerindeki etkisinin istatistiksel } \\
\text { olarak anlamlı olmadığ1 tespit edilmiştir. }\end{array}$ \\
\hline $\begin{array}{l}\text { Belen ve } \\
\text { Karamelikli } \\
\quad(2016)\end{array}$ & ARDL Yaklaşımı & $\begin{array}{l}\text { 2006:M01- } \\
\text { 2014:M12 }\end{array}$ & $\begin{array}{l}\text { Reel döviz kuru, sanayi } \\
\text { üretim endeksi, para arz1 } \\
\text { (M1), tüketici fiyat endeksi } \\
\text { ve 2008 krizi kukla değişkeni } \\
\text { - BIST100 hisse senedi } \\
\text { endeksi }\end{array}$ & $\begin{array}{l}\text { Eşbütünleşme tespit edilmiş olup uzun } \\
\text { dönem katsayılar bağlamında BIST100 } \\
\text { üzerinde tüketici fiyat endeksi ve para } \\
\text { arzı değişkenlerinin pozitif yönde; döviz } \\
\text { kuru ve sanayi üretim endeksinin ise } \\
\text { negatif yönde etki oluşturduğu tespit } \\
\text { edilmiştir. Ayrica } 2008 \text { krizini temsilen } \\
\text { oluşturulan kukla değişkeninin ise } \\
\text { BIST100 üzerinde negatif yönde etkiye } \\
\text { sahip olduğu görülmüştür. }\end{array}$ \\
\hline $\begin{array}{l}\text { Chandrashe } \\
\text { kar, } \\
\text { Sakthivel, } \\
\text { Sampath ve } \\
\text { Chittedi } \\
\text { (2018) }\end{array}$ & $\begin{array}{c}\text { Panel } \\
\text { Eşbütünleşme } \\
\text { Testi, Panel } \\
\text { Dinamik Sıradan } \\
\text { En Küçük Kareler } \\
\text { (DOLS) yaklaşımı } \\
\text { ve Heterojen Panel } \\
\text { Nedensellik Testi }\end{array}$ & $\begin{array}{l}\text { 2000:M01- } \\
\text { 2016:M08 }\end{array}$ & $\begin{array}{l}\text { Sanayi üretim endeksi, } \\
\text { tüketici fiyat endeksi, kredi } \\
\text { faiz oranı (faiz oranı) ve reel } \\
\text { efektif döviz kuru } \\
\text { değişkenleri - Brezilya ve } \\
\text { Hindistan hisse senedi } \\
\text { fiyatları }\end{array}$ & $\begin{array}{l}\text { Uzun dönem denge ilişkisi } \\
\text { (eşbütünleşme) görülmekte olup sanayi } \\
\text { üretimi ve döviz kurunun hisse senedi } \\
\text { fiyatları üzerinde pozitif yönde anlamlı } \\
\text { etkilere sahip olduğu görülmüştür. } \\
\text { Ancak tüketici fiyat endeksinin ve faiz } \\
\text { oranının ise hisse senedi fiyatlar1 } \\
\text { üzerindeki etkilerinin istatistiksel olarak } \\
\text { anlaml olmadığ1 tespit edilmiştir. } \\
\text { Bununla birlikte nedensellik testi } \\
\text { sonucuna göre hiçbir açılayıc1 } \\
\text { değişkenin hisse senedi fiyatlarının } \\
\text { nedeni olmadığı da görülmüştür. }\end{array}$ \\
\hline $\begin{array}{c}\text { Kumar } \\
(2019)\end{array}$ & $\begin{array}{c}\text { Granger } \\
\text { Nedensellik Testi } \\
\text { (Hiemstra-Jones } \\
\text { Testi) ve NARDL } \\
\text { Yaklaşımı }\end{array}$ & $\begin{array}{l}\text { 1994:M01- } \\
\text { 2015:M12 }\end{array}$ & $\begin{array}{l}\text { Petrol fiyatları ve döviz kuru } \\
\text { - S\&P BSE Sensex hisse } \\
\text { senedi endeksi }\end{array}$ & $\begin{array}{l}\text { Asimetrik nedensellikler tespit edilmiş } \\
\text { olup petrol fiyatlarını pozitif ve negatif } \\
\text { bileşenlerinin, hisse senedi fiyatlar1 } \\
\text { üzerinde istatistiksel olarak anlamlı } \\
\text { etkilere sahip oldukları tespit edilmiştir. } \\
\text { Ayrıca petrol fiyatlarının hisse senedi } \\
\text { fiyatları üzerinde uzun dönem ve kısa } \\
\text { dönem asimetrik etkilerin bulunduğu ve } \\
\text { bu iki değişken arasında çift yönlü bir } \\
\text { nedenselliğin olduğu sonucuna } \\
\text { varılmıştır. }\end{array}$ \\
\hline $\begin{array}{l}\text { El Abed ve } \\
\text { Zardoub } \\
(2019)\end{array}$ & ARDL Yaklaşımı & $\begin{array}{l}\text { 1990:Q1- } \\
\text { 2016:Q1 }\end{array}$ & $\begin{array}{l}\text { Döviz kuru, tüketici fiyat } \\
\text { endeksi, faiz oranı, para arz1 } \\
\text { (M3) ve petrol getirisi - DAX } \\
30\end{array}$ & $\begin{array}{l}\text { Eşbütünleşme ilisskisi tespit edilmiş olup } \\
\text { döviz getirisinin, para arzını ve } \\
\text { Almanya'daki petrol getirisinin hisse } \\
\text { senedi getirisi üzerindeki etkilerinin } \\
\text { istatistiksel olarak anlamlı olmadığı } \\
\text { görülmüştür. Ancak faiz oranının borsa } \\
\text { getirisi üzerinde negatif yönde anlaml } \\
\text { bir etkiye sahip olduğu bulunmuştur. } \\
\text { Diğer taraftan tüketici fiyat endeksinin } \\
\text { ise hisse senedi getirisi üzerinde pozitif } \\
\text { yönde anlamlı bir etkiye sahip olduğu } \\
\text { tespit edilmiştir. }\end{array}$ \\
\hline $\begin{array}{l}\text { Ansari ve } \\
\text { Sensarma } \\
(2019)\end{array}$ & $\begin{array}{c}\text { Vektör Otoregresif } \\
\text { Modeli }\end{array}$ & $\begin{array}{l}\text { 1996:M01- } \\
\text { 2018:M12 }\end{array}$ & $\begin{array}{l}\text { Federal fon oranı, petrol } \\
\text { fiyatı ve altın fiyatı - BRICS }\end{array}$ & $\begin{array}{l}\text { Federal Fon Oranının Hindistan Bombay } \\
\text { Sensex hisse senedi endeksi üzerinde } \\
\text { pozitif yönde anlamlı etki oluşturduğu }\end{array}$ \\
\hline
\end{tabular}




\begin{tabular}{|l|l|l|l|}
\hline & & $\begin{array}{l}\text { ülkelerinin hisse senedi } \\
\text { endeksleri }\end{array}$ & $\begin{array}{l}\text { fakat diğer endeksler üzerinde anlaml } \\
\text { etki oluşturmadiğ1 tespit edilmiştir. Ek } \\
\text { olarak Güney Afrika borsa endeksi, } \\
\text { petrol fiyatlarındaki şoklara negatif tepki } \\
\text { vermekte iken Rusya ve Brezilya borsa } \\
\text { endekslerinin ise altın fiyatlarındaki } \\
\text { değişikliklere pozitif tepki verdiği } \\
\text { görülmüştür. }\end{array}$ \\
\hline
\end{tabular}

\section{Yöntem}

\section{Araştırma modeli}

Ekonomik olaylar, birçok faktör tarafından etkilenmekte ve değişkenlik göstermektedir. Ayrıca bu durumla bağlantılı faktörler de genellikle sabit değer almayıp değişkenlik arz etmektedir. Bu kapsamda, değişkenler arasındaki ilişkinin belirlenmesi ve açılanması amacıyla matematiksel modeller kullanılmaktadır (Güriş, Çağlayan Akay ve Güriş, 2017, s. 7). Bu çerçevede, ilgili literatür incelenerek menkul kıymet borsaları üzerinde etkisi olduğu düşünülen makroekonomik faktörler belirlenmiş ve bu faktörlere ilişkin araştırma modeli oluşturulmuştur. Araştırma modelinin şekilsel ifadesi aşağıda bulunan Şekil 1'de sunulmaktadır.

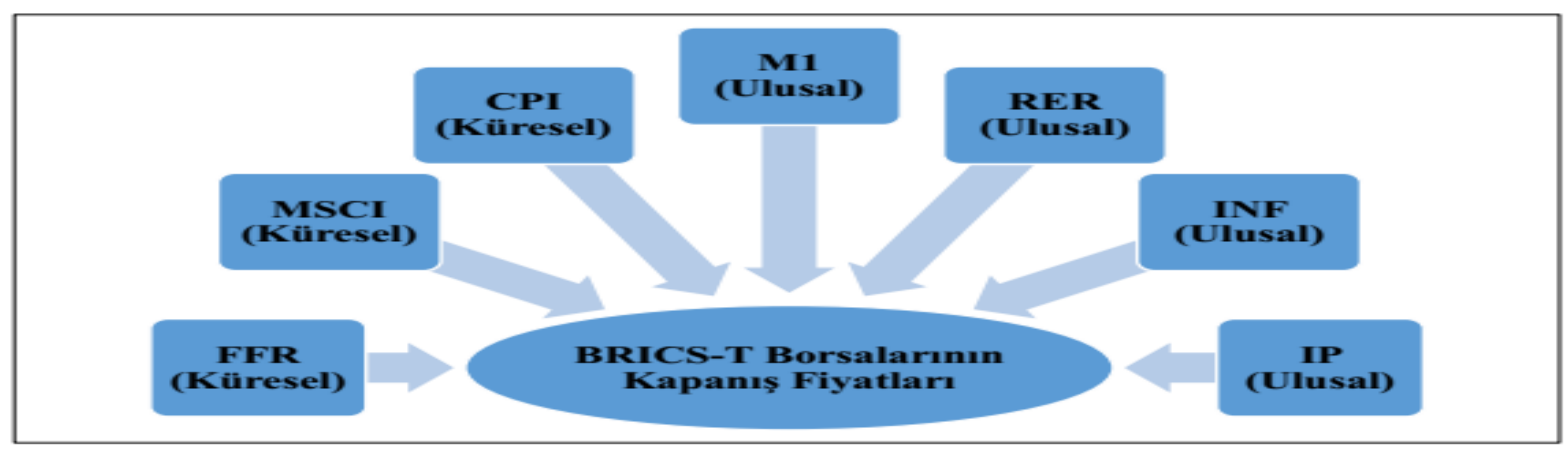

\section{Şekil 1: Araştırma Modeli}

Kaynak: Yazar tarafından üretilmiştir.

Şekil 1'de sunulan modele ilişkin yedi adet açıklayıcı değişkenden üçü küresel makroekonomik faktör (FFR: Federal Fon Oranı, MSCI: MSCI Dünya Endeksi ve CPI: Küresel Emtia Fiyat Endeksi) ve dördü ise ulusal (yerel) makroekonomik faktör (M1: Dar Tanımlı Para Arzı, RER: Reel Döviz Kuru (ABD Doları bazlı), INF: Enflasyon (Tüketici Fiyat Endeksi) ve IP: Sanayi Üretim Endeksi) olarak belirlenmiştir. Araştırma kapsamında: FFR değişkeni, küresel para piyasası (ABD para politikası göstergesi) ve M1 değişkeni ise ulusal para piyasası ile ilgili önemli iki faktör oldukları düşünülmektedir. CPI değiş̧keni, küresel talep hakkında bilgiler sunduğu ve INF (Tüketici Fiyat Endeksi - TÜFE) değişkeni ise ulusal enflasyonu gösterdiği kabul edilmektedir. MSCI Dünya Endeksi (MSCI World Index) değişkeni gelişmiş ülkelerin sermaye piyasaları (dolayısıyla küresel sermaye piyasaları) ve RER değişkeni ise ulusal ekonominin rekabet gücü ve ulusal paranın değeri hakkında bilgiler sunmaktadır. Ayrıca Pan ve Mishra (2018, s. 665) tarafından GSYİH'yi temsil etmek için en yaygın olarak kullanılan faktörün, aylık verilerine ulaşılabilen sanayi üretimi endeksinin olduğu ifade edilmektedir. Bundan dolayı IP değişkeni, ulusal ekonomik gelişimin (büyüme veya daralma) bir ölçüsü olarak kabul edildiği için modelde yer almaktadır. Gelişen ekonomilerden BRICS ülkelerinin, dünya genelindeki yükselen ekonomik paylarından ve aynı zamanda hızlı bir ekonomik dönüşüm gerçekleştirmek isteyen gelişen ve az gelişmiş ülkeler için rol model haline gelmelerinden dolayı bu ülkeler küresel ekonomi üzerinde artan bir etkiye sahiptir. Ayrıca BRICS ülkelerinin, sürdürülebilir kalkınma projelerinde artan yatırım (yerli ve yabanc1) firsatları da bulunmaktadır (Ahmed, 2017, s. 488). Bu nedenle BRICS ülkelerinin mevcut ve ileriye yönelik ekonomik büyüme potansiyelleri, bu ülkelerin Türkiye'nin yanında araştırmaya dahil edilmelerinde önemli bir rol oynamıştır.

Bu çalışmanın asıl odak noktasını oluşturan araştırma modelinin genel ve ülke bazında fonksiyonel gösterimleri:

$$
\begin{gathered}
S M P_{t}=f\left(F F R_{t}, M S C I_{t}, C P I_{t}, M 1_{t}, R E R_{t}, I N F_{t}, I P_{t}\right) \\
B I S T 100_{t}=f\left(F F R_{t}, M S C I_{t}, C P I_{t}, M 1_{t}, R E R_{t}, I N F_{t}, I P_{t}\right)
\end{gathered}
$$




$$
\begin{aligned}
& B O V E S P A_{t}=f\left(F F R_{t}, M S C I_{t}, C P I_{t}, M 1_{t}, R_{E R}, I N F_{t}, I P_{t}\right) \\
& M^{\prime} X_{t}=f\left(F F R_{t}, M S C I_{t}, C P I_{t}, M 1_{t}, R E R_{t}, I N F_{t}, I P_{t}\right) \\
& \text { NIFTY50 } 0_{t}=f\left(F F R_{t}, M S C I_{t}, C P I_{t}, M 1_{t}, R E R_{t}, I N F_{t}, I P_{t}\right) \\
& S H C O M P_{t}=f\left(F F R_{t}, M S C I_{t}, C P I_{t}, M 1_{t}, R E R_{t}, I N F_{t}, I P_{t}\right) \\
& L J T O P I_{t}=f\left(F F R_{t}, M S C I_{t}, C P I_{t}, M 1_{t}, R E R_{t}, I N F_{t}, I P_{t}\right)
\end{aligned}
$$

Denklem 3

Denklem 4

Denklem 5

Denklem 6

Denklem 7

şeklinde sunulmakta olup Denklem 1, genel fonksiyonel gösterimi ifade etmektedir. Bu fonksiyonel gösterimlerdeki: SMP, borsa endeksi kapanış fiyatını; BIST100, Türkiye Borsası için BIST100 Endeksi kapanış fiyatını; BOVESPA, Brezilya Borsası için BOVESPA Endeksi kapanış fiyatını; MOEX, Rusya Borsası için MOEX Endeksi kapanış fiyatını; NIFTY50, Hindistan Borsası için NIFTY50 Endeksi kapanış fiyatını; SHCOMP, Çin Borsası için SHCOMP Endeksi kapanış fiyatını ve JTOPI, Güney Afrika Borsası için JTOPI Endeksi kapanış fiyatını temsil etmektedir. Araştırma modelleri, Sıradan En Küçük Kareler yöntemiyle gösterildiğinde ise;

$$
\begin{aligned}
& L S M P_{t}=\beta_{0}+\beta_{1} F_{F R}+\beta_{2} L_{M S C I}+\beta_{3} L C P I_{t}+\beta_{4} L M 1_{t}+\beta_{5} L_{R E R_{t}}+\beta_{6} L_{I N F_{t}} \\
& +\beta_{7} L I P_{t}+u_{t} \\
& \operatorname{LBIST100}_{t}=\beta_{0}+\beta_{1} \text { FFR }_{t}+\beta_{2} L_{M S C I}+\beta_{3} L C P I_{t}+\beta_{4} L M 1_{t}+\beta_{5} L R E R_{t}+\beta_{6} \\
& L I N F_{t}+\beta_{7} L I P_{t}+u_{t} \\
& \text { LBOVESPA }_{t}=\beta_{0}+\beta_{1} \text { FFR }_{t}+\beta_{2} L_{M S C I}+\beta_{3} L C P I_{t}+\beta_{4} L M 1_{t}+\beta_{5} L R E R_{t}+\beta_{6} \\
& \operatorname{LINF}_{t}+\beta_{7} \mathrm{LIP}_{t}+u_{t} \\
& L M O E X_{t}=\beta_{0}+\beta_{1} F F R_{t}+\beta_{2} L M S C I_{t}+\beta_{3} L C P I_{t}+\beta_{4} L M 1_{t}+\beta_{5} L R E R_{t}+\beta_{6} \\
& L_{I N F_{t}}+\beta_{7} L I P_{t}+u_{t}
\end{aligned}
$$

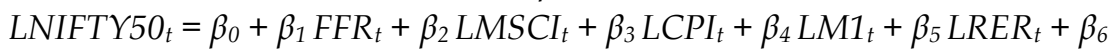

$$
\begin{aligned}
& L I N F_{t}+\beta_{7} L I P_{t}+u_{t} \\
& \operatorname{LSHCOMP}_{t}=\beta_{0}+\beta_{1} \text { FFR }_{t}+\beta_{2} L M S C I_{t}+\beta_{3} L C P I_{t}+\beta_{4} L M 1_{t}+\beta_{5} L R E R_{t}+\beta_{6} \\
& L I N F_{t}+\beta_{7} L I P_{t}+u_{t} \\
& \text { LJTOPI }_{t}=\beta_{0}+\beta_{1} \text { FFR }_{t}+\beta_{2} \text { LMSCI }_{t}+\beta_{3} L_{C P I_{t}}+\beta_{4} L M 1_{t}+\beta_{5} L R E R_{t}+\beta_{6} \\
& L I N F_{t}+\beta_{7} L I P_{t}+u_{t}
\end{aligned}
$$

denklemleri ile ifade edilebilmektedir. Denklemlerde bulunan " $\beta_{0}$ ", kesme terimini ve " $u$ " ise rassal veya stokastik hata terimini ifade etmektedir. "L" ise doğal logaritmayı ifade etmektedir. Ayrıca Türkiye ve BRICS ülkeleri bağlamında uygulanan Doğrusal ARDL yöntemi sonucunda, bu açıklayıcı değişkenlere ilişkin en fazla istatistiksel olarak anlaml etki oluşturan faktörler belirlenip bunlar Türkiye açısından değerlendirilmiştir. Değerlendirme sonucunda üç faktörün öne çıtığı görülmüş olup bunlar; global emtia fiyat endeksi (CPI), dar tanımlı para arzı (M1) ve reel döviz kuru (RER)'dur. Belirlenen bu makroekonomik faktörler bağlamında, Doğrusal Olmayan ARDL (NARDL) yaklaşımı uygulanarak araştırmaya derinlik sağlanmıştır.

\section{Analiz yöntemi}

Araştırmanın amacı dikkate alınarak verilerin uygun yöntemlerle analiz edilmesinde; birim kök testleri, ARDL yaklaşımı, NARDL yaklaşımı ve tanılayıcı testler uygulanmıştır.

\section{Birim kök testleri}

Mevcut literatürde, bazı zaman serileri durağanken bazılarının ise durağan olmadığı ortaya koyulmaktadır. Buna bağlı olarak ekonometrik analizlerden önce durağanlığın belirlenmemesi durumunda, modelde durağan olmayan zaman serileriyle araştırma süreçlerin yürütülebileceği ve olası yanlış tahminleri tanımlayan sahte regresyonlara neden olabileceği düşünülmektedir (Wanzala, 2018, s. 144).

Çalışma çerçevesinde gerçekleştirilen eşbütünleşme analizinden önce, ilgili değişkenlerin bütünleşme düzeyinin belirlenmesi önemli bir gerekliliktir. Bununla birlikte ARDL modeli, tüm değişkenlerin aynı düzeyde bütünleşmesini gerektirmemektedir ancak ARDL yaklaşımının değişkenlerin I(0) ve/veya I(1) olması, hiçbirinin I(2) veya daha yüksek düzeyde durağan olmaması zorunluluğunun doğrulanması önemlidir (Pesaran, Shin ve Smith, 2001).

Zaman serisi analizinde uygulanan modelleme tekniklerinin çoğu öncelikle verilerin durağanlığı ile ilgilidir. Başlangıç noktası, serinin özelliklerini grafik olarak incelemek ve istatistiksel olarak doğrulamaktır. Grafikler, serinin durağanlığı hakkında genel bir fikir edinilmesini sağlamaktadır. Ancak nihai karar için istatistiksel testler gerekmektedir. Bu doğrultuda birim kök testleri, belirli bir dizinin durağanlığına ilişkin istatistiksel kanıt sunmaktadır (Shrestha ve Bhatta, 2018, s. 73). 
Literatürdeki birçok çalışma, birim kökün test edilmesi için Genişletilmiş Dickey-Fuller (ADF) testini kullanmaktadır fakat ADF testi ile yapısal kırılmalar incelenememektedir. Perron (1989), ADF sonuçlarının birim kökü reddetmemeye karşı taraflı olma ihtimalinin daha yüksek olduğunu göstermektedir. Bundan dolayı, yapısal kırılmaların dikkate alınması için ADF testine bir kukla değişken eklenerek bir yapısal kırılma dışsal olarak belirlenebilmektedir. Bu durum, Zivot ve Andrews (1992) tarafından eleştirilmektedir çünkü bir yapısal kırılmanın ön seçimi, birim kökün fazlaca reddedilmesine yol açabilmektedir (Banafea, 2012, s. 35). Bu araştırmada, durağanlığın belirlenmesi için tüm değişkenlerin birim köklerinin incelenmesi, ADF, DF-GLS ve Zivot ve Andrews birim kök testleri kullanılarak yapılmıştır.

\section{Otoregresif dağıtılmış gecikme (ARDL) yaklaşımı}

Engle ve Granger (1987) veya Johansen $(1988 ; 1995)$ gibi eşbütünleşik ilişkileri tahmin etme yöntemleri veya Tam Değiştirilmiş En Küçük Kareler (Fully Modified Ordinary Least Squares - FMOLS) veya Dinamik En Küçük Kareler (Dynamic Ordinary Least Squares - DOLS) gibi yöntemler, tüm değişkenlerin I(1) olmasını veya değişkenlerin $\mathrm{I}(0)$ ve I(1) olduğu yerlerde ise ön bilgi ve tanımlama gerektirmektedir. Eşbütünleşme analizinde, Otoregresif Dağıtılmış Gecikme Modeli (Autoregressive Distributed Lag - ARDL) ise regresör değişkenlerin düzeyde durağan (I(0)), birinci farkları durağan (I(1)) ya da I(0) ve I(1) şeklinde olduğunda uygulanabilen bir yöntem olarak Pesaran ve Shin (1999) ve Pesaran vd. (2001) tarafından ortaya atılmıştır. Basit bir ifadeyle, ARDL açıklanan ve açıklayıcı değişkenlerin gecikmelerini içeren en küçük kareler regresyonudur. Bir ARDL'de $\left(p, q_{1}, \ldots, q_{k}\right)$; $p$, açıklanan değişkenin gecikme sayısı; $\mathrm{q}_{1}$, birinci açıklayıcı değişkenin gecikme sayısı ve $\mathrm{q}_{\mathrm{k}}$, $\mathrm{k}^{\prime}$ nıncı açıklayıcı değişkenin gecikme sayısı olarak ifade edilmektedir. Bir ARDL modeli Denklem 15'te sunulmuştur:

$$
\mathrm{y}_{\mathrm{t}}=\mathrm{a}+\sum_{i=1}^{p} \gamma_{i} y_{t-i}+\sum_{j=1}^{k} \sum_{i=0}^{q_{j}} X_{j, t-i^{\prime}} \beta_{j, i}+\varepsilon_{\mathrm{t}}
$$

Denklem 15

Bu model, açıklayıcı değişkenlerin, $X_{j}$ gecikmeli terimleri olmadan $\left(q_{j}=0\right)$ ortaya çıktığında, hem statik hem de sabit olanlar için dinamik regresörlere izin vermektedir. Bu kapsamda, gecikme uzunluklarını belirlemek için ortak seçim prosedürleri bulunmakta ve bir ARDL modeli, en küçük kareler regresyonu yoluyla tahmin edilebildiğinden model seçimi için standart bilgi kriterleri (AIC, BIC, vb.) kullanılabilmektedir. Ayrıca Pesaran ve Shin (1999) tarafından eşbütünleşme ilişkilerinin tahmin edilmesi için diğer yöntemlerin aksine ARDL modelinde, gecikme uzunluklarının simetrisini gerektirmediği ve her değişkenin farklı sayıda gecikme terimine sahip olabildiği göz önünde bulundurulmuştur. Bir ARDL modelinin eşbütünleştirici regresyon formu, Denklem 15'in farklara dönüştürülmesi ve bunların uzun dönem katsayılarının yerine kullanılmasıyla birlikte Denklem 16, elde edilmektedir:

$$
\Delta \mathrm{y}_{\mathrm{t}}=-\sum_{i=1}^{p-1} \gamma_{i}^{*} \Delta y_{t-1}+\sum_{j=1}^{k} \sum_{i=0}^{q_{j}-1} \Delta X_{j, t-i^{\prime}} \beta_{j, i^{*}}-\widehat{\varnothing} \mathrm{EC}_{\mathrm{t}-1}+\varepsilon_{\mathrm{t}}
$$

Denklem 16

Denklem 16'daki hata düzeltme terimi (EC) Denklem 17 ile ifade edilmektedir:

$$
\mathrm{EC}_{\mathrm{t}}=\mathrm{y}_{\mathrm{t}}-\mathrm{a}-\sum_{j=1}^{k} X_{j, t^{t}} \hat{\theta}_{j}
$$

Denklem 17

Denklem 17, uzun dönem eşbütünleşme regresyonundan gelen OLS artıklarının serisidir. Pesaran vd. (2001) tarafından eşbütünleşme ilişkisi formunun Denklem 16' da kullanılmasıyla birlikte, ARDL modelinin bağımlı değişken ile regresörler arasında düz (veya uzun dönemli) bir ilişkinin olup olmadığının test edilmesi için bir metodoloji tanımlanmaktadır. Sınır testleri prosedürü, Denklem 16'yı:

$$
\begin{gathered}
\Delta \mathrm{y}_{\mathrm{t}}=-\sum_{i=1}^{p-1} \gamma_{i}^{*} \Delta y_{t-1}+\sum_{j=1}^{k} \sum_{i=0}^{q_{j}-1} \Delta X_{j, t-1^{\prime}} \beta_{j, i}^{*}-\rho \mathrm{y}_{\mathrm{t}-1}-\mathrm{a}- \\
\sum_{j=1}^{k} X_{j, t-1}^{\prime} \delta_{j}+\varepsilon_{\mathrm{t}}
\end{gathered}
$$

Denklem 18

şeklindeki bir gösterime dönüştürmektedir. Bu bağlamda, ilişkilerin varlığının test edilmesi: $\rho=0$ ve $\delta_{1}$ $=\delta_{2}=\ldots . .=\delta_{k}=0$ ifadeleri ile basit bir form haline gelmektedir. Denklem 18'e dayanan test istatistiği, regresörlerin tümünün I(0) veya I(1) olup olmadığına bağlı olarak sıfır hipotezi (ilişki yoktur) altında farklı bir dağılıma sahiptir. Ayrıca her iki durumda da dağılım standart değildir. Pesaran vd. (2001) tarafından, tüm regresörlerin $\mathrm{I}(0)$ olduğu durumlarda ve tüm regresörlerin $\mathrm{I}(1)$ olduğu durumlarda kritik değerler sağlanmakta ve bu kritik değerlerin, regresörlerin I(0) ve I(1) şeklinde karışık olduğu daha tipik durumlar için ise sınırlar olarak kullanması önerilmektedir (Perles-Ribes, Ramon-Rodriguez, Rubia ve Moreno-Izquierdo, 2017, s. 99).

ARDL F-istatistiği, üst sınır ve alt sınır olmak üzere iki kritik değer kümesi oluşturmaktadır. Fistatistiğinin değeri, belirli bir önem seviyesinde kritik değerin üst sınırından büyükse uzun dönemli 
bir ilişkinin yokluk hipotezi reddedilmekte ve bu nedenle eşbütünleşme bulunmaktadır. Tersi durumda; eğer F-istatistiğinin değeri belirli bir önem seviyesinde kritik değerin alt sinırından daha düşükse uzun dönemli bir ilişkinin yokluk hipotezi kabul edilmekte ve bu nedenle eşbütünleşme ilişkisi bulunmamaktadır. F-istatistikleri düşük ve yüksek kritik değerler arasında kaldığında ise sonuç belirsiz (kararsız) olmaktadır. Değişkenler arasında eşbütünleşme kurulduktan sonra eşbütünleşme denklemi tahmin edilmekte ve uzun dönem hata terimi, hata düzeltme modeline (Error Correction Model - ECM) dahil edilmektedir. Bu terim, Hata Düzeltme Terimi (Error Correction Term - ECT) olarak bilinmektedir. Bu hata düzeltme teriminin katsayısı, ilişkinin kararlılı̆̆ını ve değişkenlerin hataları düzeltme hızını göstermektedir (Bouri, Jain, Biswal ve Roubaud, 2017, s. 203). Ayrıca F sinır test istatistiği düşük ve yüksek kritik değerler arasında kaldığı durumlarda yani kararsızlık durumunda, hata düzeltme terimi, eşbütünleşmenin kurulmasında faydalı bir yaklaşım olmaktadır (Kremers, Ericsson ve Dolado, 1992; Banerjee, Dolado ve Mestre, 1998).

ARDL yöntemi, bu araştırmanın temel tahmin yaklaşımını oluşturmaktadır. Bu çalışmada, temel regresyon yöntemi olarak geleneksel eşbütünleşme yöntemleri yerine ARDL yaklaşımının seçilmesinin bazı önemli nedenleri bulunmaktadır. Bu kapsamda uzun dönem denge ilişkisinin ARDL modellemesi, bir takım ekonometrik avantajlara sahiptir. Bu avantajlar bağlamında eşbütünleşme ile ilgili bazı yorumlar bulunmaktadır. Bir eşbütünleşme analizinin yapılabilmesi için verilere ait serilerin düzeyde durağan olup olmadığının belirlenmesi önemli bir gerekliliktir. Durağanlık, veri üretme sürecinin ilk iki anının zamana bağlı olmadığını göstermektedir. Ekonomik modellemede, durağan olmayan serileri diğer durağan olmayan serileri açıklamak için Sıradan En Küçük Kareler (OLS) tekniğinin kullanılması "sahte regresyon sorunu" ile sonuçlanmaktadır. Diğer taraftan, birçok durumda olduğu gibi, tahminde kullanılan değişkenlerin bütünleşme sırası kesin olarak belirlenememektedir (Pesaran ve Shin, 1999; Vasudeva, Murthy, Albert ve Okunade, 2016, s. 67-68). Eş bütünleşmenin test edildiği diğer yöntemlerden farklı olarak ARDL sınır testi, çalışmanın değişkenlerinin I(0) veya I(1) olup olmadığına veya her ikisinin bir kombinasyonuna bakılmaksızın kullanılabilmektedir. Ancak serilerden herhangi biri I(2) ve üstünde durağan olmamalıdır, aksi takdirde ARDL sınır testi uygulanamamaktadır (Singhal, Choudhary ve Biswal, 2019, s. 258). ARDL modellemesinde, eş zamanlı olarak hem kısa hem de uzun dönem katsayılarının ve gecikmeli bağımlı ve açıklayıcı değişkenlerin tahmin edilmesinde içsellik (endojenite) probleminin olmadığı görülmektedir (Vasudeva vd., 2016, s. 67-68). Diğer bir ifadeyle; ARDL yaklaşımında kısa ve uzun dönemli etkiler test edilebilmekte olup içsellik problemi çözülebilmektedir (Huang ve Huang, 2019). ARDL eşbütünleşme prosedürü yoluyla yapılan hata düzeltme modellemesi hem kısa dönemde hem de uzun dönemde nedenselliğin belirlenmesine olanak tanımaktadır. Hipotez testlerinin sadeleştirilmesinin yanında sınır yaklaşımı, küçük örneklemlerde bile, yüksek istatistiksel güce ve düşük ölçüde sapmalara sahiptir (Pesaran ve Shin, 1999; Pesaran vd., 2001; Vasudeva vd., 2016, s. 67-68).

Araştırma Modeli'nin Sıradan En Küçük Kareler (OLS) yöntemi ile tahmini, aşağıda belirtilen Denklem 19 kullanılarak (ARDL sınır yaklaşımı) yapılabilmektedir:

$$
\begin{aligned}
& \Delta \operatorname{LSMP}_{t}=\mathrm{a}_{0}+\mathrm{a}_{1} \operatorname{LSMP}_{t-1}+\mathrm{a}_{2} \mathrm{FFR}_{t-1}+\mathrm{a}_{3} \mathrm{LCPI}_{t-1}+\mathrm{a}_{4} \operatorname{LINF}_{t-1}+\mathrm{a}_{5} \operatorname{LIP}_{t-1} \\
& +a_{6} \operatorname{LM}_{t-1}+a_{7} \operatorname{LMSCI}_{t-1}+a_{8} \operatorname{LRER}_{t-1}+\sum_{i=1}^{p} \beta_{1 i} \Delta \mathrm{LSMP}_{t-i}+ \\
& \sum_{i=0}^{q_{1}} \beta_{2 i} \Delta \mathrm{FFR}_{t-i}+\sum_{i=0}^{q_{2}} \beta_{3 i} \Delta \mathrm{LCPI}_{t-i}+\sum_{i=0}^{q_{3}} \beta_{4 i} \Delta \mathrm{LINF}_{t-i}+\sum_{i=0}^{q_{4}} \beta_{5 i} \Delta \mathrm{LIP}_{t-i}+ \\
& \sum_{i=0}^{q_{5}} \beta_{6 i} \Delta \mathrm{LM}_{t-i}+\sum_{i=0}^{q_{6}} \beta_{7 i} \Delta \mathrm{LMSCI}_{t-i}+\sum_{i=0}^{q_{7}} \beta_{8 i} \Delta \mathrm{LRER}_{t-i}+u_{t}
\end{aligned}
$$

Denklem 19'daki $\Delta$, ilgili değişkenin birinci fark operatörünü; $a_{0}$, deterministik sürüklenme parametresini; $u_{t}$ ise Gaussian beyaz gürülttüyü ifade etmektedir. Ayrıca $\alpha_{1}, \alpha_{2}, \alpha_{3}, \alpha_{4}, \alpha_{5}, a_{6}, \alpha_{7}$ ve $\alpha_{8}$ ifadeleri değişkenler arasındaki uzun dönem dinamikleri göstermekteyken $\beta_{1 i}, \beta_{2 i}, \beta_{3 i}, \beta_{4 i}, \beta_{5 i}, \beta_{6 i}, \beta_{7 i}$ ve $\beta_{8 i}$ ifadeleri ise kısa dönem dinamiklerini belirtmektedir. Araştırma modeli bağlamında bir eşbütünleşme ilişkisinin olup olmadığının tespit edilebilmesi için yokluk (sıfır - null) hipotezi, $\mathrm{H}_{\mathrm{o}}$ : $\mathrm{a}_{1}=$ $\mathrm{a}_{2}=\mathrm{a}_{3}=\mathrm{a}_{4}=\mathrm{a}_{5}=\mathrm{a}_{6}=\mathrm{a}_{7}=\mathrm{a}_{8}=0$; alternatif hipotez ise $\mathrm{H}_{\mathrm{a}}: \mathrm{a}_{\mathrm{j}} \neq 0$ ile test edilebilmektedir. Bu kapsamda, hesaplanan F-istatistik değeri, Pesaran vd. (2001) tarafından belli anlamlılık düzeylerinde (0.01, 0.025, 0.05 ve 0.1$)$ sunulan alt ve üst kritik değerlerle karşılaştırılmaktadır. Hesaplanan F değeri, üst kritik değerden yüksekse eşbütünleşme olmadığını temsil eden yokluk hipotezi reddedilmektedir. Ayrıca $\mathrm{R}^{2}$ kriteri, Hannan Quinn Kriteri (Hannan Quinn Criterion - HQ), Akaike Bilgi Kriteri (Akaike Information Criterion - AIC) ve Schwarz Kriteri (Schwarz Criterion - SBC) aracılığıyla seçilen ARDL modeli kullanılarak uzun dönemli ilişki tahmin edilebilmektedir. Denklem $19^{\prime}$ da eşbütünleşme olmadığı ileri sürülen yokluk hipotezi kabul edilmediğinde, Pesaran vd. (2001), çalışma için aşağıda sunulan Denklem 20, kısitsız hata düzeltme modeli (Unrestricted Error Correction Model - ECM) ile tahminler gerçekleştirilmektedir: 


$$
\begin{aligned}
\Delta \mathrm{LSMP}_{t} & =\gamma_{0}+\sum_{i=1}^{p} \delta_{1 i} \Delta \mathrm{LSMP}_{t-i}+\sum_{i=0}^{q_{1}} \delta_{2 i} \Delta \mathrm{FFR}_{t-i}+\sum_{i=0}^{q_{2}} \delta_{3 i} \Delta \mathrm{LCPI}_{t-i} \\
+ & \sum_{i=0}^{q_{3}} \delta_{4 i} \Delta \mathrm{LINF}_{t-i}+\sum_{i=0}^{q_{4}} \delta_{5 i} \Delta \mathrm{LIP}_{t-i}+\sum_{i=0}^{q_{5}} \delta_{6 i} \Delta \mathrm{LM}_{t-i}+ \\
& \sum_{i=0}^{q_{6}} \delta_{7 i} \Delta \mathrm{LMSCI}_{t-i}+\sum_{i=0}^{q_{7}} \delta_{8 i} \Delta \mathrm{LRER}_{t-i}+\lambda \mathrm{ECT}_{\mathrm{t}-1}+u_{t}
\end{aligned}
$$

Denklem 20'deki ECT (Error Correction Term - Hata Düzletme Terimi), kalıntılardan (artık) meydana gelmekte olup $\lambda$ ise düzeltme hızı parametresini ifade etmektedir. Bu terimin negatif ve anlamlı olması önemlidir. Çünkü bu durum, kısa dönemde meydana gelen şokların (dengesizliklerin) uzun dönemde ne kadarının düzeleceği (dengeye gelmesi) hakkında bilgi vermektedir (Murthy ve Okunade, 2016, s. 69).

Hata düzeltme modelinin sonucu, kısa dönemli bir şokun ardından tekrar uzun dönemli dengeye ulaşma hızını göstermektedir. Bu çerçevede, araştırma modellerinin uygunluğunun sağlanması için çeşitli tanılayıcı testler yapılmaktadır. Bu testler aracılı̆̆ıyla, seçilen modelle ilişkili olarak serisel korelasyon ve değişen varyans kavramlarına ait bulgulara ulaşılmaktadır. Ayrıca regresyon katsayısının kararlılığının kontrol edilmesi için CUSUM (Cumulative Sum) tekniği kullanılmakta olup bu test istatistikleri kırılma noktalarına göre ifade edilebilmektedir. CUSUM istatistiğinin grafiği, 0.05 anlamlılık seviyesinin kritik sınırları dahilinde kalıyorsa tahmini gerçekleştirilen regresyon katsayılarının kararlı olduğu sonucuna ulaşılmaktadır (Jalil, Mahmood ve Idrees, 2013, s. 187-188). Çalışma bağlamında, ARDL yaklaşımı için tüm modellerde gecikme uzunluğu Akaike Bilgi Kriteri'ne (AIC) göre seçilmiş olup maksimum gecikme uzunluğu 4 olarak belirlenmiştir.

Araştırmada, Türkiye ve BRICS ülkeleri için gösterge endekslerin borsa kapanış fiyatları (SMP) ile küresel emtia fiyat endeksi (CPI), ulusal dar tanımlı para arzı (M1) ve ABD doları bazlı reel döviz kuru (RER) faktörleri arasındaki kısa ve uzun dönemli dinamiklerde asimetrik etkilerin olup olmadığının araştırılması amacıyla Shin, Yu ve Greenwood-Nimmo (2014) tarafından geliştirilen NARDL yaklaşımı kullanılmıştır. NARDL modeli, Pesaran vd. (2001) tarafından ileri sürülen doğrusal otoregresif dağıtılmış gecikmeli (ARDL) eşbütünleşme modelinin asimetrik bir şekilde genişletilmesinden meydana gelmektedir. Temel olarak NARDL yaklaşımı hem kısa hem de uzun dönemde asimetrileri tespit etme imkânı sunan dinamik bir hata düzeltme sisteminden oluşmaktadır (Shahzad, Nor, Ferrer ve Hammoudeh, 2017, s. 215). Araştırma kapsamında kullanılan değişkenlerin I(0), I(1) ya da her ikisinin bir arada olmasına bakılmaksızın geçerli sonuçlar vermesi nedeniyle büyük esneklik sunması NARDL modelinin önemli bir avantajı olarak görülmektedir (Nusair, 2016). Ayrıca NARDL yaklaşımı, gizli eşbütünleşmenin ortaya çıkarılmasını mümkün kılmakta ve böylelikle geleneksel bir lineer ortamda görünmeyen herhangi bir ilişkinin ihmal edilmesini önlemektedir. Böylece NARDL modelleme yaklaşımı; doğrusal eşbütünleşme, doğrusal olmayan (asimetrik) eşbütünleşme ve eşbütünleşme yokluğu arasında ayrım yapmayı mümkün kılmaktadır (Shahzad vd., 2017, s. 215).

Shin vd. (2014) tarafından ileri sürülen NARDL modeli, aşağıdaki asimetrik uzun dönem denge ilişkisine dayanmaktadır:

$$
y_{t}=\beta^{+} x_{t}^{+}+\beta^{-} x_{t}^{-}+\mu_{t} \quad \text { Denklem } 21
$$

bu denklemdeki $\mu_{t}$, uzun dönemli dengeden sapmaları temsil eden hata terimini; $\beta^{+}$ve $\beta^{-}$asimetrik uzun dönem parametrelerini; $x_{t}$ ise regresörlerin vektörünü temsil etmektedir. Bu çerçevede $x_{t}$;

$$
\mathrm{x}_{\mathrm{t}}=\mathrm{x}_{0}+x_{t}^{+}+x_{t}^{-}
$$

Denklem 22

olarak ayrışabilmektedir. Buradaki $x_{0}$ seçimli bir başlangıç değeridir. Ayrıca $x_{t}^{+}$ve $x_{t}^{-}$, sırasıyla $x_{t}^{\prime}$ deki pozitif ve negatif bileşenlerin birikimli toplamlarını ifade etmekte olup Denklem 23 ve $24^{\prime}$ teki gibi gösterilmektedir:

$$
\begin{array}{lr}
x_{t}^{+}=\sum_{j=1}^{t} \Delta x_{j}^{+}=\sum_{j=1}^{t} \max \left(\Delta \mathrm{x}_{\mathrm{j}}, 0\right) & \text { Denklem 23 } \\
x_{t}^{-}=\sum_{j=1}^{t} \Delta x_{j}^{-}=\sum_{j=1}^{t} \min \left(\Delta \mathrm{x}_{\mathrm{j},}, 0\right) & \text { Denklem 24 }
\end{array}
$$

Bu doğrultuda doğrusal ARDL (p,q) spesifikasyonunun yeniden düzenlenmesi sonucunda, aşağıdaki asimetrik hata düzeltme modeli olarak Denklem 25 elde edilebilmektedir:

$$
\Delta y_{t}=u+\rho y_{t-1}+\theta^{+} x_{t-1}^{+}+\theta^{-} x_{t-1}^{-}+\sum_{j=1}^{p-1} \alpha_{j} \Delta y_{t-j}+\sum_{j=0}^{q-1}\left(\pi_{j}^{+} \Delta x_{t-j}^{+}+\pi_{j}^{-} \Delta x_{t-j}^{-}\right)+\varepsilon_{t} \quad \text { Denklem } 25
$$


Denklem $25^{\prime}$ teki $\theta^{+}=-\rho \beta^{+}$ve $\theta^{-}=-\rho \beta^{-}$olarak gösterilmekte ve açıklayıcı değişkenlerdeki pozitif ve negatif değişikliklerde yapılan kısa dönemli uyarlanmalar sırasıyla $\pi_{j}^{+}$ve $\pi_{j}^{-}$tarafından gerçekleştirilmektedir. NARDL yönteminin ampirik uygulaması, doğrusal ARDL modelinde olduğu gibi aynı adımları gerektirmektedir. İlk adımda, Denklem 25'teki hata düzeltme modeli OLS ile hesaplanmaktadır. İkinci adım, sınır testi yaklaşımı kullanılan değişkenlerin seviyeleri arasında uzun dönemli bir ilişkinin olup olmadığının test edilmesidir (Shahzad vd., 2017, s. 216). Bu, aşağıdaki iki istatistikten birinin kullanılması ile yapılabilmektedir (Shin vd., 2014). Bunlardan ilki; Pesaran vd. (2001) tarafından ileri sürülen eşbütünleşmenin olmadığına $\left(\rho=\theta^{+}=\theta^{-}=0\right)$ karşı eşbütünleşmenin olduğunu $\left(\rho \neq \theta^{+} \neq \theta^{-} \neq 0\right)$ test eden FPSS ile ifade edilmektedir. İkincisi ise Banerjee vd. (1998) tarafından sunulan tistatistiği olup eşbütünleşmenin olduğu alternatifine karşı eşbütünleşmenin olmadığını test eden $t_{\text {BDM }}$ ile çözümlenmektedir. Bu iki istatistik, ilgili değişkenlerin bütünleşme sırasına bağlı standart olmayan dağılımlara sahip olduğundan Pesaran vd. (2001) tarafından geliştirilen sınır test prosedürü, NARDL yaklaşımında da kullanılmaktadır. Üçüncü adım, standart Wald testleri ile uzun dönemli simetri $\left(\beta^{+}=\beta^{-}\right)$ve kısa dönemli simetri $\left(\sum_{j=0}^{q-1} \pi_{k, j}^{+}=\sum_{j=0}^{q-1} \pi_{k, j}^{-}\right)$testlerinden oluşmaktadır. Dördüncü adımda, $x_{t}^{+}$ ve $x_{t}^{-}$ifadelerindeki bir birim değişikliğinin $\mathrm{y}_{\mathrm{t}}$ üzerindeki asimetrik kümülatif dinamik çarpan etkisiyle Denklem 26 elde edilebilmektedir:

$$
m_{h}^{+}=\sum_{j=0}^{h} \frac{\partial y_{t+j}}{\partial x_{t}^{+}} \text {ve } m_{h}^{-}=\sum_{j=0}^{h} \frac{\partial y_{t+j}}{\partial x_{t}^{-}}, \mathrm{h}=0,1,2, \ldots \ldots \ldots \ldots \ldots . . . \quad \text { Denklem } 26
$$

Denklem $26^{\prime}$ daki $h \rightarrow \infty$ iken $m_{h}^{+} \rightarrow \beta^{+}$ve $m_{h}^{-} \rightarrow \beta^{-}$olmaktadır. Ayrica $\beta^{+}$ve $\beta^{-}$ise; sirasiyla $\beta^{+}=-\theta^{+} / \rho$ ve $\beta^{-}=-\theta^{-} / \rho$ olarak hesaplanmaktadır (Shahzad vd., 2017, s. 216).

Bu bağlamda, çalışmada tahmini yapılacak NARDL modeli Denklem 27' de sunulmuştur:

$$
\begin{array}{cc}
\Delta L S M P_{t}=u+\rho L S M P_{t-1}+\theta_{1}^{+} L C P I_{t-1}^{+}+\theta_{1}^{-} L C P I_{t-1}^{-}+\theta_{2}^{+} L M 1_{t-1}^{+}+\theta_{2}^{-} L M 1_{t-1}^{-}+ & \\
\theta_{3}^{+} L R E R_{t-1}^{+}+\theta_{3}^{-} L R E R_{t-1}^{-}+\sum_{j=1}^{p-1} \alpha_{j} \Delta L S M P_{t-j}+\sum_{j=0}^{q-1} \pi_{1, j}^{+} \Delta L C P I_{t-j}^{+}+ & \text {Denklem } 27 \\
\sum_{j=0}^{q-1} \pi_{1, j}^{-} \Delta L C P I_{t-j}^{-}+\sum_{j=0}^{q-1} \pi_{2, j}^{+} \Delta L M 1_{t-j}^{+}+\sum_{j=0}^{q-1} \pi_{2, j}^{-} \Delta L M 1_{t-j}^{-}+ & \\
\sum_{j=0}^{q-1} \pi_{3, j}^{+} \Delta L R E R_{t-j}^{+}+\sum_{j=0}^{q-1} \pi_{3, j}^{-} \Delta L R E R_{t-j}^{-}+\varepsilon_{t} &
\end{array}
$$

Modeldeki (Denklem 27) $\mathrm{LCPI}^{+}$ve $\mathrm{LCPI}^{-}$sırasıyla küresel emtia fiyat endeksi için pozitif ve negatif bileşenlerin kümülatif toplamların göstermektedir. Ayrıca $L M 1^{+}$ve $L M 1^{-}$sırasıyla ulusal dar tanımlı para arzı için pozitif ve negatif bileşenlerin kümülatif toplamlarını temsil etmektedir. Son olarak ise $L R E R^{+}$ve $L R E R^{-}$sırasıyla ulusal döviz kuru (ABD doları bazlı) için pozitif ve negatif bileşenlerin kümülatif toplamlarını ifade etmekte olup L sembolü ise doğal logaritmayı temsil etmektedir. Ayrıca çalışma kapsamında, NARDL yaklaşımı için tüm modellerde maksimum gecikme uzunluğu p=12, q=12 seçilmiş olup yalnızca \%10 düzeyine kadar anlamlı etki oluşturan regresörler modellerde yer almaktadır. NARDL yaklaşımında, Pesaran vd. (2001, s. 300) tarafından ileri sürülen \% 10: 2.72-3.77; \% 5: 3.23-4.35 ve \% 1: 4.29-5.61 asimptotik kritik değerleri kullanılmıştır.

\section{Veri seti}

Ulusal ve küresel makroekonomik faktörlerin Türkiye ve BRICS (Brezilya, Rusya, Hindistan, Çin ve Güney Afrika) ülkelerine ait hisse senedi endeksleri üzerindeki etkilerinin araştırıldığı bu çalışmanın analizlerinde kullanılmak üzere Ocak 2003 - Aralık 2016 dönemine ait aylık veriler elde edilmiştir. Ayrıca bu döneme ilişkin 5544 adet veri, analizlerde kullanılmış olup bu verilerin elde edildiği kaynaklara ilişkin bilgiler Tablo 2' de sunulmaktadır. 
Tablo 2: Araştırma Verilerinin Kaynakları

\begin{tabular}{|l|l|l|}
\hline \multicolumn{1}{|c|}{ Değişken } & \multicolumn{1}{|c|}{ Açılama } & \multicolumn{1}{c|}{ Veri Kaynağı } \\
\hline $\begin{array}{l}\text { BIST100 } \\
\text { BOVESPA } \\
\text { MOEX } \\
\text { NIFTY50 } \\
\text { SHCOMP } \\
\text { JTOPI }\end{array}$ & $\begin{array}{l}\text { Borsa Istanbul 100 Hisse Senedi Endeksi } \\
\text { Bolsa de Valores de Sao Paulo Hisse Senedi } \\
\text { Endeksi } \\
\text { Moscow Exchange Hisse Senedi Endeksi } \\
\text { NSE NIFTY 50 Hisse Senedi Endeksi } \\
\text { Shanghai Composite Hisse Senedi Endeksi } \\
\text { FTSE/JSE Top 40 Hisse Senedi Endeksi }\end{array}$ & $\begin{array}{l}\text { - Yahoo Finance } \\
\text { - Investing }\end{array}$ \\
\hline FFR & Efektif Federal Fon Oranı & \\
\hline M1 & Dar Tanıml Para Arzi & - Federal Reserve Bank of St. Louis (FRED) \\
\hline MSCI World Index & $\begin{array}{l}\text { MSCI Gelişmiş Ülkeler için Sermaye Piyasası } \\
\text { Endeksi }\end{array}$ & - Federal Reserve Bank of St. Louis (FRED) \\
\hline CPI & Global Emtia Fiyat Endeksi & - Morgan Stanley Capital International (MSCI) \\
\hline RER & Reel Döviz Kuru & - The International Monetary Fund (IMF) \\
\hline INF (CPI) & Enflasyon (Tüketici Fiyat Endeksi - TÜFE) & - The International Monetary Fund (IMF) \\
\hline IP & Sanayi Üretim Endeksi & - The International Monetary Fund (IMF) \\
\hline
\end{tabular}

Tablo 2 bağlamında, Türkiye ve BRICS ülkelerine ait hisse senedi endekslerinin verileri Yahoo Finance ve Investing kapsamındaki resmi internet sitelerinden karşılaştırmalı olarak elde edilmiştir. FFR, M1 ve CPI verileri, St. Louis Merkez Bankası'ndan (Federal Reserve Bank of St. Louis - FRED) ve RER ve INF verileri, Uluslararası Para Fonu'ndan (The International Monetary Fund - IMF) sağlanmıştır. MSCI World Index verileri, Morgan Stanley Capital International kapsamındaki resmi internet sitesinden elde edilmiştir. Türkiye, Brezilya, Rusya ve Hindistan'a ait IP verilerine Uluslararası Para Fonu'ndan (The International Monetary Fund - IMF) ulaşılmışken Çin ve Güney Afrika'ya ait IP verileri ise Dünya Bankası'ndan (World Bank - WB) sağlanmıştır.

\section{Araştırmanın bulguları}

Araştırmanın bu bölümünde, doğrusal ve doğrusal olmayan ARDL yaklaşımları bağlamında elde edilen Türkiye ve BRICS ülkelerine ait bulgulara yer verilmiştir.

\section{Doğrusal ARDL yaklaşımına ilişkin bulgular}

Türkiye ve BRICS ülkelerine ait bulgulara, doğrusal ARDL yaklaşımı çerçevesinde ulaşılmış olup bu bulgular tablo formunda ifade edilmiş ve yorumlanmıştır.

Türkiye ve BRICS ülkelerine ait değişkenlerin birim kök içerip içermediklerine ilişkin uygulanan ADF ve DF-GLS birim kök testlerinin sonuçlarına göre bazı değişkenlerin $\mathrm{I}(0)$ ve/veya $\mathrm{I}(1)$ oldukları görülmüştür. Bu bağlamda, değişkenlerin durağanlığı ile ilgili son kararın verilebilmesi amacıyla daha güçlü bir test olan Zivot-Andrews Yapısal Kırılmalı Birim Kök Testi'ne başvurulmuştur. Bu ülkeler için değişkenlerin durağanlıkları genel olarak değerlendirildiğinde, modelde kullanılan tüm serilerin I(0) ve/veya I(1) oldukları anlaşılmıştır. Dolayısıyla, durağanlığa ilişkin bu bulguların, çalışmada kullanılan ARDL Sınır Testi'yle uyumlu olduğu sonucuna varılmaktadır.

Türkiye ve BRICS ülkelerinin eşbütünleşme sonuçlarına ilişkin ARDL sınır testi sonuçları aşağıda yer alan Tablo 3'te gösterilmektedir. Ayrıca bu tablodaki " $\mathrm{k}$ " modeldeki temel açıklayıcı değişken sayısını ifade etmektedir.

Tablo 3: Türkiye ve BRICS Ülkelerine İlişkin ARDL Sınır Testi Sonuçları

\begin{tabular}{|c|c|c|c|}
\hline Ülke & Test İstatistiği & Değer & $\mathbf{k}$ \\
\hline Türkiye (BIST100) & \multirow{6}{*}{ F-İstatistiği } & $3.781235^{* *}$ & 7 \\
\hline Brezilya (BOVESPA) & & $5.270420^{*}$ & 7 \\
\hline Rusya (MOEX) & & $11.28763^{*}$ & 7 \\
\hline Hindistan (NIFTY50) & & $4.041000^{* *}$ & 7 \\
\hline Çin (SHCOMP) & & $4.844332^{*}$ & 7 \\
\hline Güney Afrika (JTOPI) & & 2.228186 & 7 \\
\hline \multicolumn{4}{|c|}{ Kritik Değer Sınırları } \\
\hline \multicolumn{2}{|c|}{ Anlamlılık } & I(0) Sinir & I(1) Sinır \\
\hline \multicolumn{2}{|c|}{$10 \%$} & 2.03 & 3.13 \\
\hline \multicolumn{2}{|c|}{$5 \%$} & 2.32 & 3.5 \\
\hline \multicolumn{2}{|c|}{$1 \%$} & 2.96 & 4.26 \\
\hline
\end{tabular}

Not: * ve ** işaretleri sırasıyla \%1 ve \%5 düzeylerinde istatistiksel anlamlılı̆̆ı göstermektedir. 
Tablo 3'e göre, çalışma kapsamında gerçekleştirilen ARDL Sınır Testi sonucunda eşbütünleşmenin olmadığı yönündeki yokluk hipotezi 0.05 anlamllık düzeyinde reddedilmektedir. Diğer bir ifadeyle Türkiye, Brezilya, Rusya, Hindistan ve Çin ülkeleri için oluşturulan çalışma modeli bağlamında değişkenler arasında eşbütünleşmenin olduğu görülmektedir. Ancak, Güney Afrika kapsamında gerçekleştirilen ARDL Sınır Testi sonucunda F-istatistiği, eşbütünleşme kararının alt ve üst sınırları arasında (kararsız bölge) kalmaktadır. Bu durum, eşbütünleşmenin bulunup bulunmadığı konusunda belirsizlik barındırdığı için hata düzeltme terimine başvurmak faydalı bir yöntem olmaktadır (Kremers vd., 1992; Banerjee vd., 1998).

ARDL yöntemi için gecikme uzunluğu seçiminde Akaike Bilgi Kriteri temel alınmıştır. Bu kritere göre optimal gecikme uzunluklarına sahip modelin tahmin sonuçları için değişen varyans ve otokorelasyon durumları incelenmiştir. Bu bağlamda, değişen varyans Breusch-Pagan-Godfrey testi ve serisel korelasyon Breusch-Godfrey Serisel Korelasyon LM testi uygulanarak araştırılmıştır. Bu bağlamda Türkiye, Brezilya ve Rusya ülkelerine ilişkin oluşturulan modellerde; değişen varyans probleminin ve serisel korelasyon sorununun bulunmadığı görülmektedir. Hindistan, Çin ve Güney Afrika ülkelerine ilişkin oluşturulan modellerde serisel korelasyon sorununun bulunmadığı görülmektedir. Ancak, bu modellerde değişen varyans probleminin olduğu görülmekte olup daha tutarlı sonuçlara ulaşılması amacıyla modellere White düzeltmesi uygulanmıştır. Ayrıca modellere ilişkin Durbin-Watson istatistiğinin 2'ye yakın değerlere sahip olduğu görülmüş̧ür. Bununla birlikte, Türkiye, Brezilya, Hindistan, Çin ve Güney Afrika ülkelerine ilişkin modeller için CUSUM test grafiği için 0.05 anlamlılık düzeyinde herhangi bir kırılmanın olmadığı tespit edilmiştir. Dolayısıyla, ARDL eşbütünleşme testine ilişkin katsayıların kararlı (tutarlı) oldukları ve modellerde herhangi bir yapısal kırılmanın olmadığı sonucuna varılmaktadır. Diğer taraftan, Rusya için uygulanan CUSUM testi sonucunda yapısal kırılma tespit edilmiş olup bu yapısal kırılmaya ilişkin kukla değişken (BREAK) oluşturularak bu sorun ortadan kaldırılmıştır.

$\mathrm{Bu}$ sonuçlar birlikte değerlendirildiğinde, ARDL modeli tahmin sonuçlarının tutarlı oldukları anlaşılmaktadır. Bu kapsamda, uzun dönem katsayılarına ilişkin tahmin sonuçları aşağıda bulunan Tablo 4'te sunulmaktadır.

Tablo 4: Türkiye ve BRICS Ülkelerine İlişkin ARDL Uzun Dönem Katsayılarının Tahmin Sonuçları

\begin{tabular}{|c|c|c|c|c|c|c|}
\hline Ülke & $\begin{array}{c}\text { Türkiye } \\
\text { (BIST100) }\end{array}$ & $\begin{array}{c}\text { Brezilya } \\
\text { (BOVESPA) }\end{array}$ & $\begin{array}{c}\text { Rusya } \\
\text { (MOEX) }\end{array}$ & $\begin{array}{c}\text { Hindistan } \\
\text { (NIFTY50) }\end{array}$ & $\begin{array}{c}\text { Çin } \\
\text { (SHCOMP) }\end{array}$ & $\begin{array}{c}\text { Güney Afrika } \\
\text { (JTOPI) }\end{array}$ \\
\hline Değişken & Katsay1 & Katsay1 & Katsay1 & Katsay1 & Katsay1 & Katsay1 \\
\hline FFR & 0.007345 & $0.083745^{*}$ & $0.274403^{*}$ & $0.140180^{* *}$ & $0.317508^{* * *}$ & 0.170904 \\
\hline LCPI & $-0.294129^{* *}$ & $-0.986958^{*}$ & $0.964126^{*}$ & 0.119630 & $-1.515631^{* *}$ & $0.524565^{* * *}$ \\
\hline LINF & -1.011007 & -1.081143 & 0.611755 & 0.501196 & $-23.145656^{*}$ & 2.220029 \\
\hline LIP & 0.629372 & -0.383520 & 0.310917 & -1.751110 & 4.881166 & -1.130945 \\
\hline LM1 & $0.943906^{* *}$ & $1.412451^{* *}$ & -0.265452 & $1.624776^{* *}$ & 0.049934 & 0.293739 \\
\hline LMSCI & 0.083819 & -0.041479 & -0.006296 & -0.577842 & -0.258744 & -0.182980 \\
\hline LRER & $-1.855572^{*}$ & $-1.605590^{*}$ & $1.436961^{*}$ & -0.983415 & -9.110560 & 0.352871 \\
\hline BREAK & --- & --- & $1.125994^{*}$ & --- & -- & -- \\
\hline
\end{tabular}

Not: ${ }^{*}{ }^{* *}$ ve ${ }^{* * *}$ işaretleri sırasıyla \%1, \%5 ve \%10 düzeylerinde istatistiksel anlamlıllı̆̆ göstermektedir.

Türkiye'ye ilişkin modelin uzun dönem katsayıları incelendiğinde; LCPI, LM1 ve LRER değişkenlerinin LBIST100 değişkeni üzerinde istatistiksel olarak anlamlı etkilere sahip oldukları anlaşılmaktadır. LCPI ve LRER değişkenleri LBİST100 üzerinde negatif etkilere sahip iken, LM1 değişkeni ise pozitif bir etkiye sahiptir. Bu bağlamda, LCPI \%1 artığında LBIST100 yaklaşık \%0.29 azalmakta; LM1 \%1 artığında LBIST100 yaklaşık \%0.94 artmakta ve LRER \% 1 artığında LBIST100 yaklaşık \%1.86 azalmaktadır. Ancak, diğer değişkenlerin LBIST100 üzerindeki etkilerinin istatistiksel olarak anlamlı olmadıkları görülmektedir.

Brezilya'ya ilişkin modelin uzun dönem katsayıları incelendiğinde; FFR, LCPI, LM1 ve LRER değişkenlerinin LBOVESPA değişkeni üzerinde istatistiksel olarak anlamlı etkilere sahip oldukları anlaşılmaktadır. FFR ve LM1 değişkenleri LBOVESPA üzerinde pozitif etkilere sahip iken LCPI ve LRER değişkenleri ise negatif etkilere sahiptir. Bu bağlamda, FFR bir birim artığında LBOVESPA yaklaşık \%0.08 artmakta; LCPI \%1 artığında LBOVESPA yaklaşık \%0.99 azalmakta; LM1 \%1 artığında LBOVESPA yaklaşık \%1.41 artmakta ve LRER \%1 artığında LBOVESPA yaklaşık \%1.61 azalmaktadır. Ancak, diğer değişkenlerin LBOVESPA üzerindeki etkilerinin istatistiksel olarak anlamlı olmadıkları görülmektedir.

Rusya'ya ilişkin modelin uzun dönem katsayıları incelendiğinde; FFR, LCPI ve LRER değişkenlerinin LMOEX değişkeni üzerinde pozitif yönde ve istatistiksel olarak anlamlı etkilere sahip oldukları anlaşılmaktadır. Bu bağlamda, FFR bir birim artığında LMOEX yaklaşık \%0.27 artmakta; LCPI \%1 
artığında LMOEX yaklaşık \%0.96 artmakta ve LRER \%1 artığında LMOEX yaklaşık \%1.44 artmaktadır. Ayrıca, yapısal kırılmaya ilişkin oluşturulan BREAK değişkeninin de LMOEX üzerinde pozitif yönde ve istatistiksel olarak anlamlı bir etkiye sahip olduğu tespit edilmiştir. Ancak, diğer değişkenlerin LMOEX üzerindeki etkilerinin istatistiksel olarak anlamlı olmadıkları görülmektedir.

Hindistan'a ilişkin modelin uzun dönem katsayıları incelendiğinde; FFR ve LM1 değişkenlerinin LNIFTY50 değişkeni üzerinde pozitif yönde ve istatistiksel olarak anlamlı etkilere sahip oldukları anlaşılmaktadır. Bu bağlamda FFR bir birim artığında LNIFTY50 yaklaşık \%0.14 artmakta ve LM1 \%1 artığında LNIFTY50 yaklaşık \%1.63 artmaktadır. Ancak, diğer değişkenlerin LNIFTY50 üzerindeki etkilerinin istatistiksel olarak anlamlı olmadıkları görülmektedir.

Çin'e ilişkin modelin uzun dönem katsayıları incelendiğinde; FFR, LCPI ve LINF değişkenlerinin LSHCOMP değişkeni üzerinde istatistiksel olarak anlamlı etkilere sahip oldukları anlaşılmaktadır. Ancak, diğer değişkenlerin LSHCOMP üzerindeki etkilerinin istatistiksel olarak anlamlı olmadıkları görülmektedir. FFR değişkeni LSHCOMP üzerinde pozitif bir etkiye sahip iken LCPI ve LINF değişkenleri ise negatif etkilere sahiptir. Bu bağlamda, FFR bir birim artığında LSHCOMP yaklaşık \%0.32 artmakta ve LCPI \%1 artığında LSHCOMP yaklaşık \%1.52 azalmaktadır. LINF değişkeni ise \%1 artığında LSHCOMP yaklaşık \% 23.15 azalmakta olduğu görülmektedir. Bu büyük oran farkının iki nedenden kaynaklanabileceği düşünülmektedir. Birincisi; borsa kapanış fiyatlarının enflasyon karşısında yüksek duyarlılığa sahip olduğu ifade edilebilmekte olup bu duruma ilişkin tanımlayıcı istatistikler incelendiğinde en düşük standart sapmaya sahip olan faktörün enflasyon oranının sonrasında ise döviz kurunun olduğu görülmektedir. Çin gibi büyük bir ekonomide, göreli olarak daha stabil yapıda meydana gelen bir değişim kritik ekonomik unsurları tetikleyerek borsa fiyatları üzerinde önemli etkilere neden olabileceği söylenebilir. İkincisi ise; modelin doğrusal bağlantı problemine sahip olmasından kaynaklanabileceğidir. Doğrusal bağlantı; iki veya daha fazla açıklayıcı değişken arasında tam doğrusal ilişkinin bulunması durumuna ortaya çıkmaktadır (Gujarati, 2011, s. 68). Bu durum yalın bir ifadeyle, küçük örneklem genişliği ve/veya açıklayıcı değişkenlerin sahip olduğu değerlerde yeterince değişkenliğin olmaması şeklinde de ifade edilebilmektedir (Goldberger, 1991, s. 248-249). Bu bağlamda, araştırmada meşru bir şekilde çeşitli değişkenleri içeren bir model bulunup doğrusal bağlantı problemine neden olan değişkenler varsa bu değişkenlerin modelden çıkarılmamasının daha iyi olduğu düşünülmektedir (Gujarati, 2011, s. 75).

Güney Afrika'ya ilişkin modelin uzun dönem katsayıları incelendiğinde; LCPI değişkeninin LJTOPI değişkeni üzerinde istatistiksel olarak pozitif yönde anlamlı bir etkiye sahip olduğu anlaşılmaktadır. $\mathrm{Bu}$ bağlamda, LCPI \%1 artığında LJTOPI yaklaşık \%0.53 artmaktadır. Ancak, diğer değişkenlerin LJTOPI üzerindeki etkilerinin istatistiksel olarak anlamlı olmadıkları görülmektedir.

Türkiye ve BRICS ülkelerine ilişkin oluşturulan modellerde yer alan değişkenlerin hata düzeltme terimine ARDL yöntemi kullanılarak tahmin edilen hata düzeltme modeliyle ulaşılmıştır. Bu çerçevede, ARDL modellerinin hata düzeltme terimleri aşağıda yer alan Tablo 5 'te gösterilmektedir.

Tablo 5: Türkiye ve BRICS Ülkelerine İlişkin Hata Düzeltme Terimi Tahmin Sonuçları

\begin{tabular}{|c|c|c|c|c|c|c|}
\hline Ülke & $\begin{array}{c}\text { Türkiye } \\
\text { (BIST100) }\end{array}$ & $\begin{array}{c}\text { Brezilya } \\
\text { (BOVESPA) }\end{array}$ & $\begin{array}{c}\text { Rusya } \\
\text { (MOEX) }\end{array}$ & $\begin{array}{c}\text { Hindistan } \\
\text { (NIFTY50) }\end{array}$ & $\begin{array}{c}\text { Çin } \\
\text { (SHCOMP) }\end{array}$ & $\begin{array}{c}\text { Güney Afrika } \\
\text { (JTOPI) }\end{array}$ \\
\hline Değişkenler & Katsayılar & Katsayılar & Katsayılar & Katsayılar & Katsayılar & Katsayılar \\
\hline ECT(-1) & $-0.287420^{*}$ & $-0.177404^{*}$ & $-0.282872^{*}$ & $-0.146577^{*}$ & $-0.084559^{*}$ & $-0.142449^{*}$ \\
\hline
\end{tabular}

Not: * işareti \%1 düzeyinde istatistiksel anlamlılı̆̆1 göstermektedir.

Hata düzeltme modellerinin tahmin sonuçlarına ilişkin değişen varyans, Breusch-Pagan-Godfrey testi ve serisel korelasyon, Breusch-Godfrey Serisel Korelasyon LM testi uygulanarak araştırılmıştır.

Türkiye'ye ilişkin hata düzeltme modelinde; değişen varyans ve serisel korelasyon sorunlarının bulunmadığı tespit edilmiştir. Türkiye'ye ait araştırma modelinde bulunan hata düzeltme teriminin (ECT) negatif ve istatistiksel olarak anlamlı olduğu görülmektedir $($ ECT $(-1)=-0.287420)$. Bu terim, kısa dönemde meydana gelen şokların (dengesizliklerin) uzun dönemde ne kadarının düzeleceğine ilişkin sonuç üretmektedir. Çalışma bağlamında, bu oran yaklaşık \%29 bulunmuş olup modele ilişkin oluşturulan sistemde meydana gelen şokların bir ay içinde \%29'unun düzeltildiği sonucu çıkarılabilmektedir. Diğer bir ifadeyle, meydana gelen dengeden sapmalar yaklaşık 3.5 ayda dengeye ulaşmaktadır.

Brezilya'ya ilişkin hata düzeltme modelinde; değişen varyans ve serisel korelasyon sorunlarının bulunmadığı tespit edilmiştir. Brezilya'ya ait araştırma modelinde bulunan hata düzeltme teriminin (ECT) negatif ve istatistiksel olarak anlamlı olduğu görülmektedir $(\mathrm{ECT}(-1)=-0.177404)$. Çalışma bağlamında, bu oran yaklaşık \%18 bulunmuş olup modele ilişkin oluşturulan sistemde meydana gelen 
şokların bir ay içinde \%18'inin düzeltildiği sonucu çıkarılabilmektedir. Diğer bir ifadeyle, meydana gelen dengeden sapmalar yaklaşık 5,5 ayda dengeye ulaşmaktadır.

Rusya'ya ilişkin hata düzeltme modelinde; değişen varyans ve serisel korelasyon sorunlarının bulunmadığ1 tespit edilmiştir. Rusya'ya ait araştırma modelinde bulunan hata düzeltme teriminin (ECT) negatif ve istatistiksel olarak anlamlı olduğu görülmektedir $(\mathrm{ECT}(-1)=-0.282872)$. Çalışma bağlamında, bu oran yaklaşık \% 28 bulunmuş olup modele ilişkin oluşturulan sistemde meydana gelen şokların bir ay içinde \%28'inin düzeltildiği sonucu çıkarılabilmektedir. Diğer bir ifadeyle, meydana gelen dengeden sapmalar yaklaşık 3,5 ayda dengeye ulaşmaktadır.

Hindistan'a ilişkin hata düzeltme modelinde; değişen varyans ve serisel korelasyon sorunlarının bulunmadığı tespit edilmiştir. Hindistan'a ait araştırma modelinde bulunan hata düzeltme teriminin (ECT) negatif ve istatistiksel olarak anlamlı olduğu görülmektedir $($ ECT $(-1)=-0.146577)$. Çalışma bağlamında, bu oran yaklaşık \% 15 bulunmuş olup modele ilişkin oluşturulan sistemde meydana gelen şokların bir ay içinde \%15'inin düzeltildiği sonucu çıkarılabilmektedir. Diğer bir ifadeyle, meydana gelen dengeden sapmalar yaklaşık 6,7 ayda dengeye ulaşmaktadır.

Çin'e ilişkin hata düzeltme modelinde; serisel korelasyon sorununun bulunmadığı tespit edilmiştir. Ancak, modelde değişen varyans probleminin olduğu görülmüş olup daha tutarlı sonuçlara ulaşılması amacıyla modele White düzeltmesi uygulanmıştır. Çin'e ait araştırma modelinde bulunan hata düzeltme teriminin (ECT) negatif ve istatistiksel olarak anlamlı olduğu görülmektedir (ECT(-1) = 0.084559). Çalışma bağlamında, bu oran yaklaşık $\% 8,5$ bulunmuş olup modele ilişkin oluşturulan sistemde meydana gelen şokların bir ay içinde \% 8,5 'inin düzeltildiği sonucu çıkarılabilmektedir. Diğer bir ifadeyle, meydana gelen dengeden sapmalar yaklaşık 11,7 ayda dengeye ulaşmaktadır.

Güney Afrika'ya ilişkin hata düzeltme modelinde; hata düzeltme teriminin istatistiksel olarak güçlü bir şekilde anlamlı ve negatif değer alması $(\mathrm{ECT}(-1)=-0.142449 ; \mathrm{p}<0.01)$ modele ilişkin değişkenler arasında eşbütünleşmenin olduğu şeklinde yorumlanabilmektedir. Diğer bir ifadeyle, LJTOPI ile FFR, LCPI, LINF, LIP, LM1, LMSCI ve LRER değişkenleri arasında uzun dönemli bir ilişkinin bulunduğu kabul edilmektedir. Ayrica modelde; serisel korelasyon sorununun bulunmadığı tespit edilmiştir. Ancak, modelde değişen varyans probleminin olduğu görülmüş olup daha tutarlı sonuçlara ulaşılması amacıyla modele White düzeltmesi uygulanmıştır. Güney Afrika'ya ait araştırma modelinde bulunan hata düzeltme terimi yaklaşık \%14 bulunmuş olup modele ilişkin oluşturulan sistemde meydana gelen şokların bir ay içinde \%14'ünün düzeltildiği sonucu çıkarılabilmektedir. Diğer bir ifadeyle, meydana gelen dengeden sapmalar yaklaşık 7 ayda dengeye ulaşmaktadır.

Hata düzeltme modellerine ilişkin Durbin-Watson istatistiğinin 2'ye yakın değerlere sahip olduğu görülmüştür. Bununla birlikte, ülkelere ilişkin modeller için CUSUM test grafiği için 0.05 anlamlılık düzeyinde herhangi bir kırılmanın olmadığı tespit edilmiştir. Dolayısıyla, ARDL eşbütünleşme testine ilişkin katsayıların kararlı (tutarlı) oldukları ve modellerde herhangi bir yapısal kırılmanın olmadığı sonucuna varılmaktadır.

\section{Doğrusal olmayan ARDL yaklaşımına ilişkin bulgular}

Türkiye ve BRICS ülkeleri bağlamında uygulanan Doğrusal ARDL yöntemi sonucunda, bu açıklayıcı değişkenlere ilişkin en fazla istatistiksel olarak anlamlı etki oluşturan faktörler belirlenip bunlar Türkiye açısından değerlendirilmiştir. Değerlendirme sonucunda üç faktörün öne çıktığı görülmüş olup bunlar; global emtia fiyat endeksi (CPI), dar tanımlı para arzı (M1) ve reel döviz kuru (RER)'dur. Belirlenen bu makroekonomik faktörler bağlamında, Doğrusal Olmayan ARDL (NARDL) yaklaşımı uygulanarak araştırmaya derinlik sağlanmıştır. Bu kapsamdaki Türkiye ve BRICS ülkelerine ait bulgulara, Doğrusal Olmayan ARDL (NARDL) yaklaşımı çerçevesinde ulaşılmış olup bu bulgular tablo formunda ifade edilmiş ve yorumlanmıştır.

Türkiye ve BRICS ülkelerine ait LCPI_N, LCPI_P, LM1_N, LM1_P, LRER_N ve LRER_P değişkenlerinin birim kök içerip içermediklerine ilişkin uygulanan ADF ve DF-GLS birim kök testlerinin sonuçlarına göre bazı değiş̧enlerin $\mathrm{I}(0)$ ve/veya $\mathrm{I}(1)$ oldukları görülmüştür. Bu bağlamda, değişkenlerin durağanlığı ile ilgili son kararın verilebilmesi amacıyla daha güçlü bir test olan Zivot-Andrews Yapısal Kırılmalı Birim Kök Testi'ne başvurulmuştur. Bu ülkeler için değişkenlerin durağanlıkları genel olarak değerlendirildiğinde, modelde kullanılan tüm serilerin $\mathrm{I}(0)$ ve/veya I(1) oldukları anlaşılmıştır. Dolayısıyla, durağanlığa ilişkin bu bulguların, çalışmada kullanılan NARDL Sınır Testi yaklaşımıyla uyumlu olduğu sonucuna varılmaktadır. 
Tablo 6: Türkiye ve BRICS Ülkelerine İlişkin NARDL Sınır Testi Sonuçları

\begin{tabular}{|l|c|l|}
\hline \multicolumn{1}{|c|}{ Ülke } & F-İstatistiği & \multicolumn{1}{c|}{ Sonuç } \\
\hline Türkiye (BIST100) & $8.554200^{*}$ & Eşbütünleşme Var \\
\hline Brezilya (BOVESPA) & $5.886167^{*}$ & Eşbütünleşme Var \\
\hline Rusya (MOEX) & $5.696823^{*}$ & Eşbütünleşme Var \\
\hline Hindistan (NIFTY50) Var \\
\hline Çin (SHCOMP) & $10.17799^{*}$ & Eşbütünleşme Var \\
\hline Güney Afrika (JTOPI) & $14.71895^{*}$ & Eşbütünleşme Var \\
\hline
\end{tabular}

Not: * işareti \%1 düzeyinde istatistiksel anlamlılığı göstermektedir.

Tablo 6'ya göre, çalışma kapsamında gerçekleştirilen NARDL Sınır Testi sonucunda eşbütünleşmenin olmadığı yönündeki yokluk hipotezi 0.01 anlamlılık düzeyinde reddedilmektedir. Diğer bir ifadeyle Türkiye, Brezilya, Rusya, Hindistan, Çin ve Güney Afrika ülkeleri için oluşturulan çalışma modeli bağlamında değişkenler arasında eşbütünleşmenin olduğu görülmektedir.

NARDL yaklaşımına ilişkin modellerin tahmin sonuçları için değişen varyans ve otokorelasyon durumları incelenmiştir. Bu bağlamda, değişen varyans $\mathrm{ARCH}$ yöntemi ve serisel korelasyon BreuschGodfrey Serisel Korelasyon LM testi uygulanarak araştırılmıştır. Bu bağlamda Türkiye, Brezilya, Rusya, Hindistan, Çin ve Güney Afrika ülkelerine ilişkin oluşturulan modellerde; değişen varyans probleminin ve serisel korelasyon sorununun bulunmadığı görülmektedir. Ayrıca modellere ilişkin Durbin-Watson istatistiğinin 2'ye yakın değerlere sahip olduğu görülmüştür. Buna ek olarak ülkelere ilişkin modeller için CUSUM test grafiği için 0.05 anlamlılık düzeyinde herhangi bir kırılmanın olmadığı tespit edilmiştir. Dolayısıyla, ARDL eşbütünleşme testine ilişkin katsayıların kararlı (tutarlı) oldukları ve modellerde herhangi bir yapısal kırılmanın olmadığı sonucuna varılmaktadır.

Bu sonuçlar birlikte değerlendirildiğinde, NARDL yaklaşımı tahmin sonuçlarının tutarlı oldukları anlaşılmaktadır. Bu kapsamda, uzun dönem katsayılarına ilişkin tahmin sonuçları aşağıda bulunan Tablo 7'de sunulmaktadır.

Tablo 7: Türkiye ve BRICS Ülkelerine İlişkin NARDL Uzun Dönem Katsayılarının Tahmin Sonuçları

\begin{tabular}{|c|c|c|c|c|c|c|}
\hline Değişkenler & $\begin{array}{c}\text { Türkiye } \\
\text { (BIST100) }\end{array}$ & $\begin{array}{c}\text { Brezilya } \\
\text { (BOVESPA) }\end{array}$ & $\begin{array}{c}\text { Rusya } \\
\text { (MOEX) }\end{array}$ & $\begin{array}{c}\text { Hindistan } \\
\text { (NIFTY50) }\end{array}$ & $\begin{array}{c}\text { Çin } \\
\text { (SHCOMP) }\end{array}$ & $\begin{array}{c}\text { Güney Afrika } \\
\text { (JTOPI) }\end{array}$ \\
\hline LCPI_N & $-0.282101^{* * *}$ & $-0.740660^{*}$ & $2.233582^{* *}$ & $0.655889^{*}$ & $1.428401^{*}$ & 4.206154 \\
\hline LCPI_P & $1.113221^{*}$ & $-1.900549^{*}$ & -1.551945 & -0.110992 & 0.095823 & -8.623630 \\
\hline LM1_N & $2.117530^{* *}$ & 1.260270 & $-11.15713^{* *}$ & $4.351152^{*}$ & -1.594483 & -15.21807 \\
\hline LM1_P & $1.684626^{*}$ & 0.426225 & $4.740299^{*}$ & $2.921657^{*}$ & $3.230304^{* *}$ & -7.648447 \\
\hline LRER_N & $1.752078^{*}$ & $-4.024393^{*}$ & $3.562784^{* * *}$ & 0.680424 & $4.322861^{* * *}$ & -18.01154 \\
\hline LRER_P & $-1.890510^{*}$ & $-2.025659^{*}$ & $3.488927^{*}$ & 0.429732 & $3.484286^{* *}$ & 5.880363 \\
\hline
\end{tabular}

Not: ${ }^{*},{ }^{* *}$ ve ${ }^{* * *}$ işaretleri sırasıyla $\% 1, \% 5$ ve \%10 düzeylerinde istatistiksel anlamlılığ göstermektedir.

Tablo 7 incelendiğinde, LCPI_N, LCPI_P, LM1_N, LM1_P, LRER_N ve LRER_P değişkenlerinin LBIST100 değişkeni üzerinde istatistiksel olarak anlamlı etkilere sahip oldukları anlaşılmaktadır. LCPI_N, LCPI_P, LRER_N ve LRER_P değişkenlerinin LBOVESPA değişkeni üzerinde istatistiksel olarak anlamlı etkilere sahip oldukları anlaşılmaktadır. Ancak, LM1_N ve LM1_P değişkenlerinin LBOVESPA üzerindeki etkilerinin ise istatistiksel olarak anlamlı olmadıkları görülmektedir. LCPI_N, LM1_N, LM1_P, LRER_N ve LRER_P değişkenlerinin LMOEX değişkeni üzerinde istatistiksel olarak anlamlı etkilere sahip oldukları anlaşılmaktadır. Ancak, LCPI_P değişkeninin ise LMOEX üzerindeki etkisinin istatistiksel olarak anlamlı olmadığı görülmektedir. LCPI_N, LM1_N ve LM1_P değişkenlerinin LNIFTY50 değişkeni üzerinde istatistiksel olarak anlamlı etkilere sahip oldukları anlaşılmaktadır. Ancak, diğer değişkenlerin ise LNIFTY50 üzerindeki etkilerinin istatistiksel olarak anlamlı olmadıkları görülmektedir. LCPI_N, LM1_P, LRER_N ve LRER_P değişkenlerinin LSHCOMP üzerinde istatistiksel olarak anlamlı etkilere sahip oldukları anlaşılmaktadır. Ancak, LCPI_P ve LM1_N değişkenlerinin etkilerinin ise istatistiksel olarak anlamlı olmadıkları anlaşılmaktadır. Buna ek olarak açıklayıcı değişkenlerin LJTOPI üzerindeki etkilerinin istatistiksel olarak anlamlı olmadıkları görülmektedir.

NARDL modeline göre gerçekleştirilen Wald testi bağlamında uzun dönemde asimetrik etkilerin tahmin sonuçları aşağıda bulunan Tablo 8 ' de gösterilmektedir. 
Tablo 8: Türkiye ve BRICS Ülkelerine İlişkin Uzun Dönem Asimetrik Etkilerin Tahmin Sonuçları

\begin{tabular}{|c|c|c|c|c|c|c|}
\hline Değişkenler & $\begin{array}{c}\text { Türkiye } \\
\text { (BIST100) }\end{array}$ & $\begin{array}{c}\text { Brezilya } \\
\text { (BOVESPA) }\end{array}$ & $\begin{array}{c}\text { Rusya } \\
\text { (MOEX) }\end{array}$ & $\begin{array}{c}\text { Hindistan } \\
\text { (NIFTY50) }\end{array}$ & $\begin{array}{c}\text { Çin } \\
\text { (SHCOMP) }\end{array}$ & $\begin{array}{c}\text { Güney Afrika } \\
\text { (JTOPI) }\end{array}$ \\
\hline LCPI & $16.88170^{*}$ & $11.01822^{*}$ & $4.116764^{* *}$ & $15.36079^{*}$ & $4.486915^{* *}$ & 2.179793 \\
\hline LM1 & 0.258754 & 0.250191 & $5.457312^{* *}$ & 1.155435 & $6.907066^{*}$ & 1.718142 \\
\hline LRER & $24.01227^{*}$ & $14.07603^{*}$ & 0.003311 & 0.690042 & 0.072635 & 2.042999 \\
\hline
\end{tabular}

Not: * ve ** işaretleri sırasıyla \%1 ve \%5 düzeylerinde istatistiksel anlamlılığı göstermektedir.

Tablo 8'e göre, LBIST100 açıklanan değişkeni kapsamında LCPI ve LRER değişkenlerinin uzun dönem asimetrik etkilere sahip oldukları anlaşılmaktadır. Ancak, LM1 değişkeninin ise uzun dönem asimetrik bir etkiye sahip olmadığı görülmektedir. LBOVESPA açıklanan değişkeni kapsamında LCPI ve LRER değişkenlerinin uzun dönem asimetrik etkilere sahip oldukları anlaşılmaktadır. Ancak, LM1 değişkeninin ise uzun dönem asimetrik bir etkiye sahip olmadığı görülmektedir. LMOEX açıklanan değişkeni kapsamında LCPI ve LM1 değişkenlerinin uzun dönem asimetrik etkilere sahip oldukları anlaşılmaktadır. Ancak, LRER değişkeninin ise uzun dönem asimetrik bir etkiye sahip olmadığ1 görülmektedir. LNIFTY50 açıklanan değişkeni kapsamında LCPI değişkeninin uzun dönem asimetrik bir etkiye sahip olduğu anlaşılmaktadır. Ancak, LM1 ve LRER değişkenlerinin ise uzun dönem asimetrik etkilere sahip olmadıkları görülmektedir. LSHCOMP açıklanan değişkeni kapsamında LCPI ve LM1 değişkenlerinin uzun dönem asimetrik etkilere sahip oldukları anlaşılmaktadır. Ancak, LRER değişkeninin ise uzun dönem asimetrik bir etkiye sahip olmadığı görülmektedir. Bunlara ek olarak LJTOPI açıklanan değişkeni kapsamında açıklayıcı değişkenlerin uzun dönem asimetrik etkilere sahip olmadıkları görülmektedir.

Wald testi uygulanarak tespit edilen kısa dönem asimetrik etkilerin tahmin sonuçları aşağıda bulunan Tablo 9'da sunulmaktadır.

Tablo 9: Türkiye ve BRICS Ülkelerine İlişkin Kısa Dönem Asimetrik Etkilerin Tahmin Sonuçları

\begin{tabular}{|c|c|c|c|c|c|c|}
\hline Değişkenler & $\begin{array}{c}\text { Türkiye } \\
\text { (BIST100) }\end{array}$ & $\begin{array}{c}\text { Brezilya } \\
\text { (BOVESPA) }\end{array}$ & $\begin{array}{c}\text { Rusya } \\
\text { (MOEX) }\end{array}$ & $\begin{array}{c}\text { Hindistan } \\
\text { (NIFTY50) }\end{array}$ & $\begin{array}{c}\text { Çin } \\
\text { (SHCOMP) }\end{array}$ & $\begin{array}{c}\text { Güney Afrika } \\
\text { (JTOPI) }\end{array}$ \\
\hline LCPI & $14.95303^{*}$ & $14.38864^{*}$ & $8.407260^{*}$ & 2.308652 & $6.968221^{*}$ & $33.33024^{*}$ \\
\hline LM1 & $3.620026^{* * *}$ & $37.09853^{*}$ & 0.057574 & 0.005304 & $42.30007^{*}$ & $8.102284^{*}$ \\
\hline LRER & $13.57937^{*}$ & $3.278303^{* * *}$ & $3.414331^{* * *}$ & $32.83108^{*}$ & 1.627031 & $73.69132^{*}$ \\
\hline
\end{tabular}

Not: * ve *** işaretleri sırasıyla \%1 ve \%10 düzeylerinde istatistiksel anlamlılığ göstermektedir.

Tablo 9 incelendiğinde, LBIST100 açılanan değişkeni çerçevesinde LCPI, LM1 ve LRER değişkenlerinin kısa dönem asimetrik etkilere sahip oldukları anlaşılmaktadır. LBOVESPA açılanan değişkeni çerçevesinde LCPI, LM1 ve LRER değişkenlerinin kısa dönem asimetrik etkilere sahip oldukları anlaşılmaktadır. LMOEX açıklanan değişkeni çerçevesinde LCPI ve LRER değiş̧kenlerinin kısa dönem asimetrik etkilere sahip oldukları anlaşılmaktadır. Ancak, LM1 değişkeninin ise kısa dönem asimetrik bir etkiye sahip olmadığı görülmektedir. LNIFTY50 açılanan değişkeni çerçevesinde LRER değişkeninin kısa dönem asimetrik bir etkiye sahip olduğu anlaşılmaktadır. Ancak, LCPI ve LM1 değişkenlerinin ise kısa dönem asimetrik etkilere sahip olmadıkları görülmektedir. LSHCOMP bağımlı değişkeni çerçevesinde LCPI ve LM1 değişkenlerinin kısa dönem asimetrik etkilere sahip oldukları görülmektedir. Ancak, LRER değişkeninin ise kısa dönem asimetrik bir etkiye sahip olmadığ1 görülmektedir. LJTOPI açıklanan değişkeni çerçevesinde LCPI, LM1 ve LRER değişkenlerinin kısa dönem asimetrik etkilere sahip oldukları görülmektedir.

\section{Sonuç, tartışma ve öneriler}

$\mathrm{Bu}$ araştırma, küresel ve ulusal makroekonomik faktörlerin Türkiye ve BRICS (Brezilya, Rusya, Hindistan, Çin ve Güney Afrika) ülkelerine ait hisse senedi endeksleri üzerindeki etkilerinin belirlenmesi amacıyla ele alınmış ve hazırlanmıştır. Bu bağlamda; federal fon oranı, küresel emtia fiyat endeksi, MSCI gelişmiş ülkeler için sermaye piyasası endeksi, tüketici fiyat endeksi, sanayi üretim endeksi, dar tanımlı para arzı ve ABD Doları bazlı reel döviz kuru makroekonomik faktörler olarak araştırmada yer almaktadır. Çalışmada, değişkenlere ilişkin Ocak 2003-Aralık 2016 dönemi aylık verileri, doğrusal ve doğrusal olmayan ARDL yaklaşımlarında kullanılarak araştırma bulgularına ulaşılmıştır. Bu kapsamda elde edilen bulgular; değerlendirilerek, yorumlanarak ve karşılaştırılarak araştırma sonuçlarına dönüştürülmüştür.

ABD para politikası göstergesinin Türkiye ve BRICS ülkelerine ait hisse senedi endeksleri üzerindeki etkileri incelendiğinde bu makroekonomik faktörün; Brezilya, Rusya, Hindistan ve Çin ülkelerine ait borsa endeksleri üzerinde istatistiksel olarak pozitif yönde anlamlı etkilere sahip olduğu görülmüştür. Diğer bir ifadeyle daralma yönlü bir ABD para politikası eğilimi, bu ülkelerin borsa endeksleri üzerinde 
olumlu etkilere sahiptir. Diğer taraftan araştırma bulgularına göre ABD para politikasının Türkiye ve Güney Afrika ülkelerine ait borsa endeksleri üzerinde istatistiksel olarak anlamlı bir etkiye sahip olmadığı anlaşılmıştır. Bu bulgular, önceki bazı araştırmalar dikkate alınarak değerlendirdiğinde sonuçların; Yusof ve Majid (2007), Majid ve Yusof (2009), Hsu ve Chiang (2011) ve Adesanmi (2018) tarafından yapılan çalışmaların sonuçlarıyla tutarlı olduğu, Ansari ve Sensarma (2019) tarafından yapılan çalışmanın sonucuyla kısmen tutarlı olduğu ancak Laopodis (2006) tarafından yapılan çalışmanın sonucuyla ise tutarlı olmadığı görülmektedir. Bu faktör kapsamında temel beklenti; federal fon oranındaki bir artışın faiz oranlarını artırması ve bunun sonucu olarak da hisse senedi fiyatlarının düşmesi şeklinde ifade edilebilmektedir. Ancak Ansari ve Sensarma (2019) tarafından yapılan çalışmada, Hindistan Bombay Sensex Endeksi üzerinde federal fon oranının pozitif yönde anlamlı bir etkiye sahip olduğu tespit edilmiştir. FFR'deki artışın, yakın zamanda ABD ekonomisindeki toparlanmanın bir işareti olarak haber yayılımının etkisiyle Hindistan piyasalarında iyimserliğin artmasının, pozitif etkinin olası bir nedeni olduğu ileri sürülmüştür (Wongswan, 2009, s. 354; Ansari ve Sensarma, 2019, s. 142-143). Ayrıca daha yüksek federal fon oranının sermaye çıkışlarına neden olacağı ve bu doğrultuda Hindistan para biriminin, ihracatı artıracak şekilde bir değer düşüklüğüne sahip olacağı öngörülmektedir. Bu durumun sonucu olarak da hisse senedi fiyatlarının artabileceği ifade edilmiştir (Ansari ve Sensarma, 2019, s. 143). Bu sonuçla ilgili bir diğer bakış açısına göre Federal Fon Oranları' nın belirsizliğge duyarlılık gösterdiği ve bir belirsizlik şoku karşısında ABD Merkez Bankası'nın faiz oranını düşürme eğilimi (genişleme yönlü para politikası) sergilediği ifade edilmekte olup bundan dolayı hisse senedi fiyatlarındaki düşüşün, belirsizlikten kaynaklanabileceği ve muhtemel çelişkili faiz hareketlerinden ise kaynaklanmadığı ileri sürülmüştür (Chulia, Guillen ve Uribe, 2017, s. 27). Ek olarak para politikasının varlık fiyatlarına eşzamanlı bir tepki olmadığını varsayan temel tanımlama göz önüne alındığında, dış para politikası sıkılaştırılmasına bir tepki olarak hisse senedi fiyatlarının istikrarlı bir şekilde arttığı uzun dönemli durumlardan söz edilmektedir (Gali ve Gambetti, 2015, s. 256).

Küresel emtia fiyatlarının Türkiye ve BRICS ülkelerine ait hisse senedi endeksleri üzerindeki etkileri değerlendirildiğinde bu makroekonomik faktörün; Türkiye, Brezilya ve Çin ülkelerine ait borsa endeksleri üzerinde istatistiksel olarak negatif yönde anlamlı etkilere sahip olduğu görülmüştür. Başka bir ifadeyle küresel emtia fiyatlarının artması, bu ülkelerin borsa endeksleri üzerinde olumsuz etkilere sahip olmaktadır. Ayrıca bu makroekonomik faktörün, Rusya ve Güney Afrika ülkelerine ait borsa endeksleri üzerinde ise istatistiksel olarak pozitif yönde anlamlı etkilere sahip olduğu görülmüştür. Diğer bir anlatımla küresel emtia fiyatlarının artması, bu ülkelerin borsa endeksleri üzerinde olumlu etkilere sahip olmaktadır. Ancak araştırma bulgularına göre bu faktörün Hindistan borsa endeksi üzerinde istatistiksel olarak anlamlı bir etkiye sahip olmadığı anlaşılmaktadır. Bu bulgular, önceki bazı araştırmalar dikkate alınarak değerlendirdiğinde sonuçların; Graham vd. (2016) tarafından yapılan çalışmanın sonuçlarıyla tutarlıyken Adesanmi (2018) tarafından yapılan çalışmanın sonucuyla ise kısmen tutarsız olduğu görülmüştür. Bu sonuçlar çerçevesinde, ticari malların (emtia) ekonomik koşullara tepki gösterdiği (Graham vd., 2016, s. 425) ve BRICS ülkeleri, bazı stratejik ticari mallar için dünyanın en büyük üreticilerinden biri olup ayn zamanda bu ülkelerin küresel emtia tüketicileri arasında yer aldığı da görülmektedir (Mensi, Hammoudeh, Reboredo ve Nguyen, 2014). Açıklamalar çerçevesinde; bu ülkeler tarafından üretimde, iç ve diş ticarette, iç tüketimde vb. farklı emtia tür ve miktarlarına ihtiyaç duyulduğu için bu makroekonomik faktöre olan duyarlılıkların da farklı olduğu düşünülmektedir.

Ulusal enflasyonun Türkiye ve BRICS ülkelerine ait hisse senedi endeksleri üzerindeki etkileri incelendiğinde bu makroekonomik faktörün, Çin'e ait borsa endeksi üzerinde istatistiksel olarak negatif yönde anlamlı bir etkiye sahip olduğu görülmüştür. Bir başka anlatımla ulusal enflasyonun artması, bu ülkenin borsa endeksi üzerinde olumsuz bir etkiye sahiptir. Diğer taraftan araştırma bulgularına göre bu makroekonomik faktörün; Türkiye, Brezilya, Rusya, Hindistan ve Güney Afrika ülkelerine ait borsa endeksleri üzerinde istatistiksel olarak anlamlı bir etkiye sahip olmadığı anlaşılmaktadır. Bu bulgular, önceki bazı araştırmalar dikkate alınarak değerlendirdiğinde sonuçların; Mukherjee ve Naka (1995), Maghayereh (2003), Laopodis (2006), Humpe ve Macmillan (2009) ve Forson ve Janrattanagul (2014) tarafından yapılan çalışmaların sonuçlarıyla tutarlıyken Kandir (2008), Sayılgan ve Süslü (2011) ve Belen ve Karamelikli (2016) tarafından yapılan çalışmaların sonuçlarıyla ise tutarsız olduğu görülmüştür. Bu sonuçlar çerçevesinde Fama'nın (1981) Temsil Etkisi Yaklaşımı, reel faaliyetlerin hisse senedi getirileriyle pozitif korelasyon göstermesi durumu, hisse senedi getirileri ile enflasyon arasındaki negatif ilişkiyi ortaya koymaktadır. Bu bağlamda enflasyonun gelecek reel faaliyetler üzerindeki muhtemel olumsuz etkisi nedeniyle bu durumun borsa üzerinde negatif bir etki oluşturabileceği sonucuna varılmaktadır. Ayrıca bu negatif etkiye ilişkin sonuçların, Feldstein ve Horioka (1980) ve Geske ve Roll (1983) tarafından ileri sürülen yaklaşımlarla da tutarlı olduğu düşünülmektedir. 
Ulusal ekonomik büyümenin Türkiye ve BRICS ülkelerine ait hisse senedi endeksleri üzerindeki etkileri incelendiğinde bu makroekonomik faktörün, bu ülkeler bağlamında istatistiksel olarak anlamlı bir etkiye sahip olmadığı tespit edilmiştir. Diğer bir ifadeyle ekonomik büyümenin, bu ülkelerin borsa endeksleri üzerinde istatistiksel olarak belirleyici bir makroekonomik faktör olmadığı görülmüştür. Bu bulgular önceki bazı araştırmalar dikkate alınarak değerlendirdiğinde: Sonuçların; Kandir (2008) ve Majid ve Yusof (2009) tarafından yapılan çalışmaların sonuçlarıyla tutarlı olduğu görülmektedir. Ancak, Mukherjee ve Naka (1995), Durukan (1999), Maghayereh (2003), Humpe ve Macmillan (2009), Mohammed vd. (2009), Hsu ve Chiang (2011), Forson ve Janrattanagul (2014), Belen ve Karamelikli (2016) ve Chandrashekar vd. (2018) tarafından yapılan çalışmaların sonuçlarıyla tutarsız ve Yusof ve Majid (2007) ve Adesanmi (2018) tarafından yapılan çalışmaların sonuçlarıyla kısmen tutarsız olduğu görülmektedir. Araştırma sonuçlarındaki bu çeşitliliğe; incelenen dönemlerin, örnekleme ilişkin iç ve dış dinamiklerin ve/veya araştırma yöntemlerinin farklı olmasının neden olabileceği düşünülmektedir.

Ulusal para piyasası göstergesinin Türkiye ve BRICS ülkelerine ait hisse senedi endeksleri üzerindeki etkileri incelendiğinde bu makroekonomik faktörün; Türkiye, Brezilya ve Hindistan ülkelerine ait borsa endeksleri üzerinde istatistiksel olarak pozitif yönde anlamlı etkilere sahip olduğu görülmüştür. Diğer bir ifadeyle ekonomik genişlemeye yönelik bir ulusal para politikası eğilimi, bu ülkelerin borsa endeksleri üzerinde olumlu etkilere sahiptir. Ancak araştırma bulgularına göre bu makroekonomik faktörün; Rusya, Çin ve Güney Afrika ülkelerine ait borsa endeksleri üzerinde istatistiksel olarak anlamlı bir etkiye sahip olmadığı anlaşılmaktadır. Bu bulgular önceki bazı araştırmalar dikkate alınarak değerlendirdiğinde sonuçların; Mukherjee ve Naka (1995), Majid ve Yusof (2009), Forson ve Janrattanagul (2014) ve Belen ve Karamelikli (2016) tarafından yapılan çalışmaların sonuçlarıyla tutarlı olduğu görülmektedir. Ayrıca Durukan (1999), Maghayereh (2003), Kandir (2008) ve Sayılgan ve Süslü (2011) tarafından yapılan çalışmaların sonuçlarıyla kısmen tutarlı olduğu anlaşılmaktadır. Ancak Humpe ve Macmillan (2009) tarafından yapılan çalışmanın sonucuyla ise kısmen tutarsız olduğu sonucuna varılmaktadır. Para arzının pozitif etkisi bağlamında sonuçlar değerlendirildiğinde bu durum; para arzında meydana gelen bir artışın faiz oranlarını düşürerek likiditenin artmasını sağlayabileceği ve dolayısıyla hisse senedi fiyatlarının yükselebileceği şeklinde ifade edilebilmektedir (Thorbecke, 1997; Sellin, 2001; Sayılgan ve Süslü, 2011).

Gelişmiş ülkelerin sermaye piyasalarının Türkiye ve BRICS ülkelerine ait hisse senedi endeksleri üzerindeki etkileri değerlendirildiğinde bu makroekonomik faktörün, bu ülkeler bağlamında istatistiksel olarak anlamlı bir etkiye sahip olmadığı tespit edilmiştir. Diğer bir ifadeyle gelişmiş ülkelerin sermaye piyasaları endeksinin, Türkiye ve BRICS ülkelerine ait hisse senedi endeksleri üzerinde etkili bir makroekonomik faktör olmadığı görülmüştür. Bu bulgular önceki bazı araştırmalar dikkate alınarak değerlendirdiğinde sonuçların; Wang ve Iorio (2007) tarafından yapılan çalışmanın sonucuyla tutarlı ve Li (2013) tarafından yapılan çalışmanın sonucuyla kısmen tutarlı olduğu görülmektedir. Ancak Kandir (2008) tarafından yapılan çalışmanın sonucuyla tutarsız ve Adesanmi (2018) tarafından yapılan çalışmanın sonucuyla kısmen tutarsız olduğu görülmektedir. Araştırma sonuçlarındaki bu farklılıkların; incelenen dönemlerin, örnekleme ilişkin iç ve dış dinamiklerin ve/veya araştırma yöntemlerinin değişik olmasından kaynaklanabileceği düşünülmektedir.

Ulusal paranın değerinin Türkiye ve BRICS ülkelerine ait hisse senedi endeksleri üzerindeki etkileri incelendiğinde bu makroekonomik faktörün, Türkiye ve Brezilya ülkelerine ait borsa endeksleri üzerinde istatistiksel olarak negatif yönde anlamlı etkilere sahip olduğu görülmüştür. Diğer bir ifadeyle ulusal paranın değerinin düşmesi, bu ülkelerin borsa endeksleri üzerinde olumsuz etkilere sahip olup ABD Dolarına duyarlı bir eğilim sergilemektedirler. Bulgular Rusya bağlamında değerlendirildiğinde ise bu makroekonomik faktörün bu ülkenin borsa endeksi üzerinde istatistiksel olarak pozitif yönde anlamlı bir etkiye sahip olduğu tespit edilmiştir. Başka bir anlatımla ulusal paranın değerinin düşmesi, bu ülkenin borsa endeksi üzerinde olumlu bir etkiye sahip olduğu söylenebilmektedir. Ancak araştırma sonuçlarına göre bu makroekonomik faktörün; Hindistan, Çin ve Güney Afrika ülkelerine ait borsa endeksleri üzerinde istatistiksel olarak anlamlı bir etkiye sahip olmadığı anlaşılmaktadır. Bu bulgular önceki bazı araştırmalar dikkate alınarak değerlendirdiğinde sonucun; Yusof ve Majid (2007), Mohammed vd. (2009), Majid ve Yusof (2009), Sayılgan ve Süslü (2011), Montes ve Tiberto (2012) ve Belen ve Karamelikli (2016) tarafından yapılan çalışmaların sonuçlarıyla tutarlı ve Durukan (1999) tarafından yapılan çalışmanın sonucuyla kısmen tutarlı olduğu görülmektedir. Ancak Mukherjee ve Naka (1995), Kandir (2008) ve Chandrashekar vd. (2018) tarafından yapılan çalışmaların sonuçlarıyla tutarsız ve Adesanmi (2018) tarafından yapılan çalışmanın sonucuyla kısmen tutarsız olduğu görülmektedir.

Sonuçlar döviz kurunun anlamlı etkisi bağlamında değerlendirildiğinde bu durumun, Dornbusch ve Fischer (1980) tarafından ileri sürülen Mal Piyasası Yaklaşımı ile tutarlı olduğu görülmektedir. Bu 
kapsamda, döviz kuru dalgalanmalarının hisse senedi piyasasının üzerindeki etkisi; firmaların baskın bir şekilde net ihracatçı veya net ithalatçı olup olmamasına, yabancı bağlı ortaklıklara sahip olup olmadıklarına ve döviz kuru dalgalanmalarına karşı korumalı olup olmadıklarına bağlıdır (Tian ve Ma, 2010, s. 491). Dolayısıyla Rusya'nın ihracat açısından yoğun bir ülke olduğu (World Bank, 2019a) göz önünde bulundurulduğunda yabancı paranın değerinin yükselmesi ihracattan kaynaklanan faydaların da yükselmesine neden olabileceği ve bu durumun borsa endeksi üzerinde pozitif etkiye sahip olabileceği düşünülmektedir. Diğer taraftan Türkiye için ise ihracata kıyasla ithalatın daha yüksek olduğu (2003:M01-2016:M12 dönemi boyunca) (World Bank, 2019b) dikkate alındı̆̆ında yabancı paranın değerinin yükselmesi, ithalattan kaynaklanan parasal faydaların düşmesine neden olabileceği ve bu durumun borsa endeksi üzerinde negatif bir etkiye sahip olabileceği sonucuna varılmaktadır. Sonuç, Brezilya bağlamında değerlendirildiğinde ABD ithalatındaki bir artış, Latin Amerika Ülkelerinin (Arjantin, Brezilya, Şili ve Meksika) ihracatında artışı ve yerel para biriminin değer kazanmasını sağlamakta olup bu ülkelerin iç ekonomik aktivitesindeki bu artış, yerel sermaye piyasasında bir artışa neden olacak şekilde firmaların karını arttırmaktadır (Diamandis ve Drakos, 2011, s. 385). Ayrıca araştırma dönemi (2003:M01-2016:M12) boyunca her ne kadar Brezilya'nın dış ticaretinin fazla verme eğilimi bulunsa da (2014 yılı hariç) ülke ticaretinde (ihracat-ithalat bağlamında) ABD ve ithalat nispeten önemli bir yer tutmaktadır (World Bank, 2019c). Bu açılamalar birlikte değerlendirildiğinde; Brezilya sermaye piyasasının ABD'nin ekonomik faaliyetiyle ilişkili olduğu ve buna bağlı olarak ABD Doları bazlı döviz kuruyla bağlantılı olduğu sonucu çıkarılabilmektedir. Dolayısıyla Brezilya ulusal parasının dolar karşısında değerinin düşmesi, ithalattan kaynaklanan parasal faydaların düşmesine neden olabileceği ve bu durumun borsa endeksi üzerinde negatif etkiye sahip olabileceği sonucuna varılmaktadır.

Araştırma, hata düzeltme modelleri bağlamında değerlendirildiğinde ise Türkiye ve BRICS ülkelerinin borsalarına ait araştırma modellerinin tümü için eşbütünleşmenin olduğu kabul edilmiştir. Ayrıca bu modeller için hata düzeltme terimlerinin negatif ve istatistiksel olarak anlamlı oldukları görülmüştür. Diğer bir ifadeyle araştırma modellerine göre oluşturulan bir yapıda meydana gelen şokların veya dengeden sapmaların, çalışma kapsamında her ülkeye göre tespit edilmiş bir oranda düzeltildiği sonucuna varılmıştır. Bu bağlamda, şokların en hızlı dengeye ulaştığı ülkelerin Türkiye ve Rusya; en yavaş ülkenin ise Çin olduğu tespit edilmiştir. Diğer bir ifadeyle bu dengeden sapmaların, Türkiye'de ve Rusya'da araştırma kapsamındaki diğer ülkelere nispeten daha hızlı; Çin' de ise nispeten daha yavaş düzeldiği şeklinde de ifade edilebilmektedir.

Küresel emtia fiyatları değişkenine ait pozitif ve negatif bileşenlerin Türkiye ve BRICS ülkelerine ilişkin hisse senedi endeksleri üzerindeki etkileri değerlendirildiğinde negatif bileşen bağlamında dikkate alınan negatif şokların, Türkiye ve Brezilya ülkelerine ait borsa endeksleri üzerindeki etkisinin pozitif olduğu görülmüştür. Başka bir ifadeyle bu faktörde meydana gelen bir azalmanın, BIST100 ve BOVESPA Endekslerine ait hisse senedi fiyatlarını artırma yönlü etkilediği tespit edilmiştir. Diğer taraftan bu şokların; Rusya, Hindistan ve Çin ülkelerine ait borsa endeksleri üzerindeki etkisinin negatif olduğu bulunmuştur. Diğer bir deyişle bu faktörde meydana gelen bir azalmanın, MOEX, NIFTY50 ve SHCOMP Endekslerine ait hisse senedi fiyatlarını azalma yönlü etkilediği belirlenmiştir. Ayrıca bu şokların, Güney Afrika'ya ait hisse senedi endeksi üzerindeki etkisinin istatistiksel olarak anlamlı olmadığı görülmüştür. Pozitif bileşen bağlamında dikkate alınan pozitif şokların ise Türkiye'ye ait borsa endeksi üzerindeki etkisinin de pozitif olduğu görülmüştür. Başka bir ifadeyle bu faktörde meydana gelen bir artışın, BIST100 Endeksi'ne ait hisse senedi fiyatlarını artırma yönlü etkilediği tespit edilmiştir. Diğer taraftan bu şokların, Brezilya'ya ait borsa endeksi üzerindeki etkisinin negatif olduğu bulunmuştur. Diğer bir deyişle bu faktörde meydana gelen bir artışı, BOVESPA Endeksi'ne ait hisse senedi fiyatlarını azalma yönlü etkilediği belirlenmiştir. Ayrıca bu şokların; Rusya, Hindistan, Çin ve Güney Afrika ülkelerine ait hisse senedi endeksleri üzerindeki etkisinin istatistiksel olarak anlamlı olmadığı görülmüştür.

Küresel emtia fiyatlarının negatif ve pozitif bileşenlerinin Türkiye ve BRICS ülkelerine ait hisse senedi endeksleri üzerindeki uzun dönemli asimetrik etkileri incelendiğinde bu faktörün; Türkiye, Brezilya, Rusya, Hindistan ve Çin ülkelerine ait borsa endeksleri üzerinde uzun dönem asimetrik etkilere sahip olduğu görülmektedir. Diğer bir ifadeyle bu ülkelere ait borsa endeksleri tarafından küresel emtia fiyat endeksinin pozitif ve negatif bileşenlerine karşı gösterilen uzun dönem duyarlılıklarının farklı olduğu tespit edilmiştir. Bu çerçevede, Türkiye ve Brezilya ülkelerinin borsa endeksleri tarafından pozitif bileşene karşı gösterilen duyarlılıkların daha yüksek olduğu fakat Rusya, Hindistan ve Çin ülkelerinin borsa endeksleri tarafından ise negatif bileşene karşı gösterilen duyarlılıkların daha yüksek olduğu ve pozitif bileşenlerin istatistiksel olarak anlamlı olmadığı sonucuna varılmıştır. Diğer taraftan bu faktörün, Güney Afrika'ya ait borsa endeksi üzerinde uzun dönem asimetrik bir etkiye sahip olmadığ1 anlaşılmıştır. 
Para arzı değişkenine ait pozitif ve negatif bileşenlerin Türkiye ve BRICS ülkelerine ilişkin hisse senedi endeksleri üzerindeki etkileri değerlendirildiğinde negatif bileşen bağlamında dikkate alınan negatif şokların, Rusya'ya ait borsa endeksi üzerindeki etkisinin pozitif olduğu görülmüştür. Başka bir ifadeyle bu faktörde meydana gelen bir azalmanın, MOEX Endeksi'ne ait hisse senedi fiyatlarını artırma yönlü etkilediği tespit edilmiştir. Diğer taraftan bu şokların, Türkiye ve Hindistan ülkelerine ait borsa endeksleri üzerindeki etkisinin negatif olduğu bulunmuştur. Diğer bir deyişle bu faktörde meydana gelen bir azalmanın, BIST100 ve NIFTY50 Endekslerine ait hisse senedi fiyatlarını azalma yönlü etkilediği belirlenmiş̧ir. Ayrıca bu şokların; Brezilya, Çin ve Güney Afrika hisse senedi endeksleri üzerindeki etkisinin istatistiksel olarak anlamlı olmadığı görülmüştür. Pozitif bileşen bağlamında dikkate alınan pozitif şokların ise Türkiye, Rusya, Hindistan ve Çin ülkelerine ait borsa endeksleri üzerindeki etkisinin de pozitif olduğu görülmüştür. Başka bir ifadeyle bu faktörde meydana gelen bir artışın; BIST100, MOEX, NIFTY50 ve SHCOMP Endekslerine ait hisse senedi fiyatlarını artırma yönlü etkilediği tespit edilmiştir. Ancak bu şokların, Brezilya ve Güney Afrika hisse senedi endeksleri üzerindeki etkisinin istatistiksel olarak anlamlı olmadığı bulunmuştur.

Ulusal para piyasası göstergesinin negatif ve pozitif bileşenlerinin Türkiye ve BRICS ülkelerine ait hisse senedi endeksleri üzerindeki uzun dönemli asimetrik etkileri incelendiğinde bu faktörün, Rusya ve Çin ülkelerine ait borsa endeksleri üzerinde uzun dönem asimetrik etkilere sahip olduğu görülmektedir. Diğer bir ifadeyle bu ülkelerin borsa endeksleri tarafından dar tanımlı para arzının pozitif ve negatif bileşenlerine karşı gösterilen uzun dönem duyarlılıklarının farklı olduğu tespit edilmiştir. Bu kapsamda, Çin borsa endeksi tarafından pozitif bileşene karşı gösterilen duyarlılığın daha yüksek olduğu ve negatif bileşenin istatistiksel olarak anlamlı olmadığı fakat Rusya borsa endeksi tarafından ise negatif bileşene karşı gösterilen duyarlılığın daha yüksek olduğu sonucuna varılmıştır. Diğer taraftan bu faktörün; Türkiye, Brezilya, Hindistan ve Güney Afrika ülkelerine ait borsa endeksleri üzerinde ise uzun dönem asimetrik bir etkisinin olmadığı anlaşılmıştır.

Döviz kuru değişkenine ait pozitif ve negatif bileşenlerin Türkiye ve BRICS ülkelerine ilişkin hisse senedi endeksleri üzerindeki etkileri değerlendirildiğinde negatif bileşen bağlamında dikkate alınan negatif şokların, Brezilya'ya ait borsa endeksi üzerindeki etkisinin pozitif olduğu görülmüştür. Başka bir ifadeyle bu faktörde meydana gelen bir azalmanın, BOVESPA Endeksine ait hisse senedi fiyatlarını artırma yönlü etkilediği tespit edilmiştir. Diğer taraftan bu şokların; Türkiye, Rusya ve Çin ülkelerine ait borsa endeksleri üzerindeki etkisinin negatif olduğu bulunmuştur. Diğer bir deyişle bu faktörde meydana gelen bir azalmanın, BIST100, MOEX ve SHCOMP Endekslerine ait hisse senedi fiyatların azalma yönlü etkilediği belirlenmiştir. Ayrıca bu şokların, Hindistan ve Güney Afrika hisse senedi endeksleri üzerindeki etkisinin istatistiksel olarak anlamlı olmadığı görülmüştür. Pozitif bileşen bağlamında dikkate alınan pozitif şokların ise Rusya ve Çin ülkelerine ait borsa endeksleri üzerindeki etkisinin de pozitif olduğu görülmüştür. Başka bir ifadeyle bu faktörde meydana gelen bir artışın, MOEX ve SHCOMP Endekslerine ait hisse senedi fiyatlarını artırma yönlü etkilediği tespit edilmiştir. Diğer taraftan bu şokların, Türkiye ve Brezilya ülkelerine ait borsa endeksleri üzerindeki etkisinin negatif olduğu bulunmuştur. Diğer bir deyişle bu faktörde meydana gelen bir artışın, BIST100 ve BOVESPA Endekslerine ait hisse senedi fiyatlarını azalma yönlü etkilediği belirlenmiştir. Ayrıca bu şokların, Hindistan ve Güney Afrika hisse senedi endeksleri üzerindeki etkisinin istatistiksel olarak anlamlı olmadığı bulunmuştur.

Ulusal paranın değerinin negatif ve pozitif bileşenlerinin Türkiye ve BRICS ülkelerine ait hisse senedi endeksleri üzerindeki uzun dönemli asimetrik etkileri incelendiğinde bu faktörün, Türkiye ve Brezilya ülkelerine ait borsa endeksleri üzerinde uzun dönem asimetrik etkilere sahip olduğu görülmektedir. Diğer bir ifadeyle bu ülkelerin borsa endeksleri tarafından ulusal paranın değerinin pozitif ve negatif bileşenlerine karşı gösterilen uzun dönem duyarlılıklarının farklı olduğu tespit edilmiştir. Bu çerçevede, Türkiye'ye ait borsa endeksi tarafından pozitif bileşene karşı gösterilen duyarlılığın daha yüksek olduğu fakat Brezilya'ya ait borsa endeksi tarafından ise negatif bileşene karşı gösterilen duyarlılığın daha yüksek olduğu sonucuna varılmıştır. Diğer taraftan bu faktörün; Rusya, Hindistan, Çin ve Güney Afrika ülkelerine ait borsa endeksleri üzerinde uzun dönem asimetrik bir etkiye sahip olmadığı anlaşılmıştır.

Araştırma sonucunda literatüre katkı sağlayacak yeni bilgilere ulaşılmış olup çalışma sonuçlarının politika yapıcılara, yatııımılara ve araştırmacılara bazı önemli faydaları bulunmaktadır. Bu bağlamda sonuçlar, politika yapıcıların araştırma kapsamındaki faktörlere bağlı olarak yönetim stratejilerini belirlemelerine yardımcı olabilmektedir. Yatırımcılar, bu makroekonomik faktörlerin koşullarına dayalı olarak ortaya çıkan borsa endeksi fiyatlarındaki değişimi tahmin edilebilmekte ve dolayısıyla araştırma sonuçları, bu değişimi tahmin etme maliyetinin azalmasına yardımcı olabilmektedir. Buna bağlı olarak sonuçların, yatırımcılara bu faktörlerde meydana gelen bir değişim karşısında ilgili borsalardaki yatırım 
pozisyonlarının seyrine ilişkin bilgiler sunduğu düşünülmektedir. Yapılacak araştırmalarda, analizlere sayıca daha fazla gelişen ülkeye ait hisse senedi piyasaları dahil edilerek araştırmanın kapsamı genişletilebilir. Araştırmanın zaman periyodu, Türkiye ve BRICS ülkelerine ilişkin Ocak 2003 - Aralık 2016 dönemi aylık verilerini içermektedir. Yapılacak araştırmalarda zaman periyodu ve frekansı çeşitlendirilerek literatüre katkı sağlayacak yeni sonuçlara ulaşılabilir. Araştırmanın örneklemi kapsamındaki ülkelere ilişkin tek bir gösterge hisse senedi endeksi kullanılmıştır. Bu bağlamda bazı ülkeler (Rusya, Hindistan, Çin ve Güney Afrika) birden fazla gösterge endekse sahip olduğundan, ülke özelinde ve/veya BRICS topluluğu çerçevesinde diğer hisse senedi endeksleri de analizlere dahil edilerek araştırma sonuçları çeşitlendirilebilir. Ayrıca farklı ülkeler (gelişmiş ve/veya gelişen ülkeler) seçilerek değişik ekonometrik modellerin kullanılması durumunda çalışma sonuçlarından daha farklı bulgulara ulaşılması mümkündür.

\section{Hakem Değerlendirmesi / Peer-review:}

Dış bağımsız

Externally peer-reviewed

\section{Çıkar Çatışması / Conflict of interests:}

Yazar(lar) çıkar çatışması bildirmemiştir.

The author(s) has (have) no conflict of interest to declare.

\section{Finansal Destek/ Grant Support:}

Yazar(lar) bu çalışma için finansal destek almadığını beyan etmiştir.

The author(s) declared that this study has received no financial support.

\section{Yazar Katkıları / Author Contributions:}

Fikir/Kavram/Tasarım - Idea/Concept/Design: İ.K., M.İ., Veri Toplama ve/veya İşleme - Data Collection and/or Processing: İ.K., Analiz ve/veya Yorum - Analysis and/or Interpretation: İ.K., Kaynak Taraması Literature Review: İ.K., Makalenin Yazımı - Writing the Article: İ.K., M.İ., Eleştirel İnceleme - Critical Review: İ.K., M.I.., Onay - Approval: M.İ.

\section{Kaynakça / References}

Adesanmi, A. A. (2018). The Impact of National and Global Macroeconomic Factors on Emerging Stock Markets: A Multi-Statistical Analysis of the MINT Countries. Yayımlanmamış Doktora Tezi. Cardiff Metropolitan University.

Ahmed, K. (2017). Revisiting the Role of Financial Development for Energy-Growth-Trade nexus in BRICS Economies. Energy, 128, 487-495.

Ansari, M. G., \& Sensarma, R. (2019). US Monetary Policy, Oil and Gold Prices: Which has a Greater Impact on BRICS Stock Markets? Economic Analysis and Policy, 64, 130-151.

Bacik, G. (2013). Turkey and the BRICS: Can Turkey Join the BRICS? Turkish Studies, 14(4), 758-773.

Banafea, W. A. (2012). Essays on Structural Breaks and Stability of the Money Demand Function. Yayımlanmamış Doktora Tezi. Kansas State University, College of Arts and Sciences, Department of Economics, Kansas.

Banerjee, A., Dolado, J. J., \& Mestre R. (1998). Error-Correction Mechanism Tests for Co-Integration in Single Equation Framework. Journal of Time Series Analysis, 19(3), 267-283. 
Barry, C. B., Peavy, J. W., \& Rodriguez, M. (1998). Performance Characteristics of Emerging Capital Markets. Financial Analysts Journal, 54(1), 72-80.

Belen, M., \& Karamelikli, H. (2016). Türkiye'de Hisse Senedi Getirileri ile Döviz Kuru Arasındaki İlişkinin İncelenmesi: ARDL Yaklaşım. İstanbul Üniversitesi İşletme Fakültesi Dergisi, 45(1), 34-42.

Bouri, E., Jain, A., Biswal, P. C., \& Roubaud, D. (2017). Cointegration and Nonlinear Causality Amongst Gold, Oil, and the Indian Stock Market: Evidence from Implied Volatility Indices. Resources Policy, $52,201-206$.

Chandrashekar, R., Sakthivel, P., Sampath, T., \& Chittedi, K. R. (2018). Macroeconomic Variables and Stock Prices in Emerging Economies: A Panel Analysis. Theoretical \& Applied Economics, 25(3), 91-100.

Chkili, W. (2016). Dynamic Correlations and Hedging Effectiveness between Gold and Stock Markets: Evidence for BRICS Countries. Research in International Business and Finance, 38, 22-34.

Chulia, H., Guillen, M., \& Uribe, J. M. (2017). Measuring Uncertainty in the Stock Market. International Review of Economics \& Finance, 48, 18-33.

Diamandis, P. F., \& Drakos, A. A. (2011). Financial Liberalization, Exchange Rates and Stock Prices: Exogenous Shocks in Four Latin America Countries. Journal of Policy Modeling, 33(3), 381-394.

Dornbusch, R., \& Fischer, S. (1980). Exchange Rates and the Current Account. American Economic Review, 70(5), 960-971.

Dritsaki, M. (2005). Linkage between Stock Market and Macroeconomic Fundamentals: Case Study of Athens Stock Exchange. Journal of Financial Management and Analysis, 18(1), 38-47.

Durukan, M. B. (1999). İstanbul Menkul Kıymetler Borsasında Makroekonomik Değişkenlerin Hisse Senedi Fiyatlarına Etkisi. IMKB Dergisi, 3(11), 19-47.

El Abed, R., \& Zardoub, A. (2019). Exploring the Nexus between Macroeconomic Variables and Stock Market Returns in Germany: An ARDL Co-Integration Approach. Theoretical \& Applied Economics, 2(2), 139-148.

Engle, R. F., \& Granger, C. W. J. (1987). Co-Integration and Error Correction: Representation, Estimation, and Testing. Econometrica, 55(2), 251-276.

Fama, E. F. (1981). Stock Returns, Real Activity, Inflation, and Money. The American Economic Review, 71(4), 545-565.

Feldstein, M., \& Horioka, C. (1980). Domestic Saving and International Capital Flows. The Economic Journal, 90(358), 314-329.

Forson, J. A., \& Janrattanagul, J. (2014). Selected Macroeconomic Variables and Stock Market Movements: Empirical Evidence from Thailand. Contemporary Economics, 8(2), 157-174.

Gali, J., \& Gambetti, L. (2015). The Effects of Monetary Policy on Stock Market Bubbles: Some Evidence. American Economic Journal: Macroeconomics, 7(1), 233-257.

Gan, C., Lee, M., Yong, H. H. A., \& Zhang, J. (2006). Macroeconomic Variables and Stock Market Interactions: New Zealand Evidence. Investment Management and Financial Innovations, 3(4), 89-101.

Geske, R., \& Roll, R. (1983). The Fiscal and Monetary Linkage between Stock Returns and Inflation. The Journal of Finance, 38(1), 1-33.

Goldberger, A. (1991). A Course in Econometrics. Cambridge, MA: Harvard University Press.

Graham, M., Peltomaki, J., \& Piljak, V. (2016). Global Economic Activity as an Explicator of Emerging Market Equity Returns. Research in International Business and Finance, 36, 424-435.

Gujarati, D. (2011). Econometrics by Example (1st Edition). London: Palgrave Macmillan.

Güriş, S., Çağlayan Akay, E., \& Güriş, B. (2017). EViews ile Temel Ekonometri (3. Baskı). İstanbul: Der Kitabevi Yayınevi ve Dağıtım.

Hosseini, S. M., Ahmad, Z., \& Lai, Y. W. (2011). The Role of Macroeconomic Variables on Stock Market Index in China and India. International Journal of Economics and Finance, 3(6), 233-243.

Hsu, K. C., \& Chiang, H. C. (2011). Nonlinear Effects of Monetary Policy on Stock Returns in a Smooth Transition Autoregressive Model. The Quarterly Review of Economics and Finance, 51(4), 339-349. 
Huang, Z., \& Huang, L. (2019). Individual New Energy Consumption and Economic Growth in China. North American Journal of Economics and Finance. 22 Temmuz 2019 tarihinde https:// doi.org/10.1016/j.najef.2019.101010 adresinden erişildi.

Humpe, A., \& Macmillan, P. (2009). Can Macroeconomic Variables Explain Long-Term Stock Market Movements? A Comparison of the US and Japan. Applied Financial Economics, 19, 111-119.

Jalil, A., Mahmood, T., \& Idrees, M. (2013). Tourism-Growth nexus in Pakistan: Evidence from ARDL Bounds Tests. Economic Modelling, 35, 185-191.

Jiang, Y., Fu, Y., \& Ruan, W. (2019). Risk Spillovers and Portfolio Management between Precious Metal and BRICS Stock Markets. Physica A: Statistical Mechanics and its Applications. 23 Temmuz 2019 tarihinde https:// doi.org/10.1016/j.physa.2019.04.229 adresinden erişildi.

Johansen, S. (1988). Statistical Analysis of Cointegrating Vectors. Journal of Economic Dynamics and Control, 12, 231-254.

Johansen, S. (1995). Likelihood-Based Inference in Cointegrated Vector Autorregressive Models. New York: Oxford University Press Incorporated.

Kandir, S. Y. (2008). Macroeconomic Variables, Firm Characteristics and Stock Returns: Evidence from Turkey. International Research Journal of Finance and Economics, 16, 35-45.

Karan, M. B. (2011). Yatırım Analizi ve Portföy Yönetimi. Ankara: Gazi Kitabevi.

Kremers, J. J. M., Ericsson, N. R., \& Dolado, J. J. (1992). The Power of Cointegration Tests. Oxford Bulletin of Economics and Statistics, 54, 325-348.

Kumar, A. (2011). An Empirical Analysis of Causal Relationship between Stock Market and Macroeconomic Variables India. International Journal of Computer Science \& Management Studies, 11(1), $8-14$.

Kumar, S. (2019). Asymmetric Impact of Oil Prices on Exchange Rate and Stock Prices. The Quarterly Review of Economics and Finance, 72, 41-51.

Laopodis, N. T. (2006). Dynamic Interactions among the Stock Market, Federal Funds Rate, Inflation, and Economic Activity. The Financial Review, 41, 513-545.

Levine, R. (1991). Stock Markets, Growth, and Tax Policy. The Journal of Finance, 46(4), 1445-1465.

Levine, R., \& Zervos, S. (1998). Stock Market, Banks, and Economic Growth. The American Economic Review, 88(3), 537-558.

Li, H. (2013). Integration Versus Segmentation in China's Stock Market: An Analysis of Time-Varying Beta Risks. Journal of International Financial Markets, Institutions and Money, 25, 88-105.

Maghayereh, A. (2003). Causal Relations among Stock Prices and Macroeconomic Variables in the Small, Open Economy of Jordan. Journal of King Abdulaziz University: Economics and Administration, 17(2), 312.

Majid, M. S. A., \& Yusof, R. M. (2009). Long-Run Relationship between Islamic Stock Returns and Macroeconomic Variables: An Application of the Autoregressive Distributed Lag Model. Humanomics, 25(2), 127-141.

Mensi, W., Hammoudeh, S., Nguyen, D. K., \& Kang, S. H. (2016). Global Financial Crisis and Spillover Effects among the U.S. and BRICS Stock Markets. International Review of Economics \& Finance, 42, 257276.

Mensi, W., Hammoudeh, S., Reboredo, J. C., \& Nguyen, D. K. (2014). Do Global Factors Impact BRICS Stock Markets? A Quantile Regression Approach. Emerging Markets Review, 19, 1-17.

Mohammed, S. D., Hussain, A., Jalil, M. A., \& Ali, A. (2009). Impact of Economics Variables on Stock Prices: Emperical Evidance in Case of KSE. European Journal of Scientific Research, 38(1), 96-103.

Montes, G. C., \& Tiberto, B. P. (2012). Macroeconomic Environment, Country Risk and Stock Market Performance: Evidence for Brazil. Economic Modelling, 29(5), 1666-1678.

Moorkerjee, R., \& Yu, O. (1997). Macroeconomic Variables and Stock Prices in a Small Open Economy: The Case of Singapore. Pasific-Basin Finance Journal, 5, 377-388. 
Mukherjee, T. T., \& Naka, A. (1995). Dynamic Relations between Macroeconomic Variables and the Japanese Stock Market: An Application of a Vector Error Correction Model. The Journal of Financial Research, 18(2), 223-237.

Murthy, V. N. R., \& Okunade, A. A. (2016). Determinants of U.S. Health Expenditure: Evidence from Autoregressive Distributed Lag (ARDL) Approach to Cointegration. Economic Modelling, 59, 67-73.

Nasseh, A., \& Strauss, J. (2000). Stock Prices and Domestic and International Macroeconomic Activity: A Cointegration Approach. The Quarterly Review of Economics and Finance, 40(2), 229-245.

Nusair, S. A. (2016). The Effects of Oil Price Shocks on the Economies of the Gulf Cooperation Council Countries: Nonlinear Analysis. Energy Policy, 91, 256-267.

Pan, L., \& Mishra, V. (2018). Stock Market Development and Economic Growth: Empirical Evidence from China. Economic Modelling, 68, 661-673.

Perles-Ribes, J. F., Ramon-Rodriguez, A. B., Rubia, A., \& Moreno-Izquierdo, L. (2017). Is the TourismLed Growth Hypothesis Valid after the Global Economic and Financial Crisis? The Case of Spain 1957-2014. Tourism Management, 61, 96-109.

Perron, P. (1989). The Great Crash, the Oil-Price Shock, and the Unit Root Hypothesis. Econometrica, 57(6), 1361-1401.

Pesaran, M. H., \& Shin, Y. (1999). An Autoregressive Distributed Lag Modelling Approach to Cointegration Analysis (Chapter 11). In S. Strom (Ed.), Econometrics and Economic Theory in the 20th Century: The Ragnar Frisch Centennial Symposium, Cambridge University Press, 371-413.

Pesaran, M. H., Shin, Y., \& Smith, R. (2001). Bounds Testing Approaches to the Analysis of Level Relationships. Journal of Applied Econometrics, 16, 289-326.

Raza, N., Shahzad, S. J. H., Tiwari, A. K., \& Shahbaz, M. (2016). Asymmetric Impact of Gold, Oil Prices and their Volatilities on Stock Prices of Emerging Markets. Resources Policy, 49, 290-301.

Sayılgan, G., \& Süslü, C. (2011). Makroekonomik Faktörlerin Hisse Senedi Getirilerine Etkisi: Türkiye ve Gelişmekte Olan Piyasalar Üzerine Bir İnceleme. BDDK Bankacllk ve Finansal Piyasalar Dergisi, 5(1), 73-96.

Sellin, P. (2001). Monetary Policy and the Stock Market: Theory and Empirical Evidence. Journal of Economic Surveys, 15(4), 491-541.

Sevinç, E. (2014). Makroekonomik Değişkenlerin, BIST-30 Endeksinde İşlem Gören Hisse Senedi Getirileri Üzerindeki Etkilerinin Arbitraj Fiyatlama Modeli Kullanarak Belirlenmesi. İstanbul Üniversitesi İşletme Fakültesi Dergisi, 43(2), 271-292.

Shahzad, S. J. H., Nor, S. M., Ferrer, R., \& Hammoudeh, S. (2017). Asymmetric Determinants of CDS Spreads: U.S. Industry-Level Evidence through the NARDL Approach. Economic Modelling, 60, 211230.

Shin, Y., Yu, B., \& Greenwood-Nimmo, M. (2014). Modelling Asymmetric Cointegration and Dynamic Multipliers in a Nonlinear ARDL Framework. In: R. C. Sickles \& W. C. Horrace (Ed.), Festschrift in Honor of Peter Schmidt Econometric Methods and Applications, Springer, New York, 281-314.

Shrestha, M. B., \& Bhatta, G. R. (2018). Selecting Appropriate Methodological Framework for Time Series Data Analysis. The Journal of Finance and Data Science, 4(2), 71-89.

Singhal, S., Choudhary, S., \& Biswal, P. C. (2019). Return and Volatility Linkages among International Crude Oil Price, Gold Price, Exchange Rate and Stock Markets: Evidence from Mexico. Resources Policy, 60, 255-261.

Tadesse, S. (2004). The Allocation and Monitoring Role of Capital Markets: Theory and International Evidence. Journal of Financial and Quantitative Analysis, 39(4), 701-730.

Thorbecke, W. (1997). On Stock Market Returns and Monetary Policy. The Journal of Finance, 52(2), 635654 .

Tian, G. G., \& Ma, S. (2010). The Relationship between Stock Returns and the Foreign Exchange Rate: The ARDL Approach. Journal of the Asia Pacific Economy, 15(4), 490-508.

Vasudeva, N. R., Murthy, V. N. R., Albert, A., \& Okunade, A. A. (2016). Determinants of U.S. Health Expenditure: Evidence from Autoregressive Distributed Lag (ARDL) Approach to Cointegration. Economic Modelling, 59, 67-73. 
Wang, Y., \& Iorio, A. D. (2007). Are the China-Related Stock Markets Segmented with Both World and Regional Stock Markets? Journal of International Financial Markets, Institutions and Money, 17(3), 277290.

Wanzala, R. W. (2018). Estimation of Market Immediacy by Coefficient of Elasticity of Trading Three Approach. The Journal of Finance and Data Science, 4(3), 139-156.

Wongswan, J. (2009). The Response of Global Equity Indexes to U.S. Monetary Policy Announcements. Journal of International Money and Finance, 28(2), 344-365.

World Bank (2019a). Russian Federation Trade Statistics: Exports, Imports, Products, Tariffs, GDP and Related Development Indicator. World Integrated Trade Solution (WITS). 10 Ağustos 2019 tarihinde https:// wits.worldbank.org/CountryProfile/en/RUS adresinden erişildi.

World Bank (2019b). Turkey Trade Statistics: Exports, Imports, Products, Tariffs, GDP and Related Development Indicator. World Integrated Trade Solution (WITS). 11 Ağustos 2019 tarihinde https:// wits.worldbank.org/CountryProfile/en/TUR adresinden erişildi.

World Bank (2019c). Brazil Trade Statistics: Exports, Imports, Products, Tariffs, GDP and Related Development Indicator. World Integrated Trade Solution (WITS). 11 Ağustos 2019 tarihinde https:// wits.worldbank.org/CountryProfile/en/BRA adresinden erişildi.

Yılmaz, Ö., Güngör, B., \& Kaya, V. (2008). Hisse Senedi Fiyatları ve Makroekonomik Değişkenler Arasındaki Eşbütünleşme ve Nedensellik. İMKB Dergisi, 9(34), 1-16.

Yusof, R. M., \& Majid, M. S. A. (2007). Macroeconomic Variables and Stock Returns in Malaysia: An Application of the ARDL Bound Testing Approach. Savings and Development, 31(4), 449-469.

Zivot, E., \& Andrews, D. W. K. (1992). Further Evidence on the Great Crash, the Oil-Price Shock, and the Unit-Root Hypothesis. Journal of Business \& Economic Statistics, 10(3), 251-270. 